\title{
RESEARCH
}

Open Access

\section{Vulnerability and resilience to Alzheimer's disease: early life conditions modulate neuropathology and determine cognitive reserve}

Sylvie L. Lesuis ${ }^{1 *}$, Lianne Hoeijmakers ${ }^{1}$, Aniko Korosi ${ }^{1}$, Susanne R. de Rooij ${ }^{1,2}$, Dick F. Swaab ${ }^{3}$, Helmut W. Kessels ${ }^{3,4}$, Paul J. Lucassen ${ }^{1+}$ and Harm J. Krugers ${ }^{1+}$

\begin{abstract}
Background: Alzheimer's disease (AD) is a progressive neurodegenerative disorder with a high prevalence among the elderly and a huge personal and societal impact. Recent epidemiological studies have indicated that the incidence and age of onset of sporadic AD can be modified by lifestyle factors such as education, exercise, and (early) stress exposure. Early life adversity is known to promote cognitive decline at a later age and to accelerate aging, which are both primary risk factors for AD. In rodent models, exposure to 'negative' or 'positive' early life experiences was recently found to modulate various measures of AD neuropathology, such as amyloid-beta levels and cognition at later ages. Although there is emerging interest in understanding whether experiences during early postnatal life also modulate $A D$ risk in humans, the mechanisms and possible substrates underlying these long-lasting effects remain elusive.

Methods: We review literature and discuss the role of early life experiences in determining later age and AD-related processes from a brain and cognitive 'reserve' perspective. We focus on rodent studies and the identification of possible early determinants of later AD vulnerability or resilience in relation to early life adversity/enrichment.

Results: Potential substrates and mediators of early life experiences that may influence the development of $A D$ pathology and cognitive decline are: programming of the hypothalamic-pituitary-adrenal axis, priming of the neuroinflammatory response, dendritic and synaptic complexity and function, overall brain plasticity, and proteins such as early growth response protein 1 (EGR1), activity regulated cytoskeleton-associated protein (Arc), and repressor element-1 silencing transcription factor (REST).

Conclusions: We conclude from these rodent studies that the early postnatal period is an important and sensitive phase that influences the vulnerability to develop AD pathology. Yet translational studies are required to investigate whether early life experiences also modify AD development in human studies, and whether similar molecular mediators can be identified in the sensitivity to develop AD in humans.
\end{abstract}

Keywords: Resilience, Vulnerability, Early life, Stress, Neonatal handling, Hypothalamic-pituitary-adrenal axis, EGR1, REST, Arc, Aging

\footnotetext{
* Correspondence: S.L.Lesuis@uva.nl

†Paul J. Lucassen and Harm J. Krugers contributed equally to this work.

'Brain Plasticity Group, SILS-CNS, University of Amsterdam, Science Park 904,

1098 XH Amsterdam, The Netherlands

Full list of author information is available at the end of the article
}

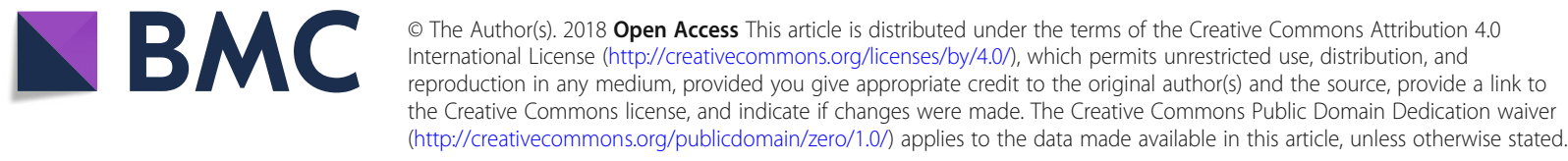




\section{Background}

Alzheimer's disease (AD) is a neurodegenerative disorder that is highly prevalent among the elderly population. $\mathrm{AD}$ is characterised by progressive impairments in various behavioural and cognitive functions [1] that have a profound impact on AD patients, their families, caregivers, and society. Prominent neuropathological hallmarks in the brains of $\mathrm{AD}$ patients include amyloid-beta $(\mathrm{A} \beta)$ peptidecontaining plaques and neurofibrillary tangles (NFTs) containing hyperphosphorylated tau. In humans and rodents, the gradual accumulation of $\mathrm{A} \beta$-containing plaques and NFTs has been associated, among other things, with spine loss and glial activation. Together, they may trigger the age-related cognitive decline and behavioural symptoms characteristic of AD [2]. Seminal genetic studies have identified mutations in the amyloid precursor protein (APP), Presenilin-1, and Presenilin-2 genes and variations in $\mathrm{ApoE}$ in relation to early and late-onset familial AD (see e.g. [3-5]). While these mutations explain a small percentage of $\mathrm{AD}$ cases, the vast majority of cases probably have a multifactorial aetiology, in which both age and lifestyle factors play an important modulatory role [4, 6-8]. Epidemiological studies have shown that factors like higher education, a more healthy diet, more social and physical activities, bilingualism, and measures for lifelong learning and mental stimulation correlate with a slower rate of memory decline during aging, a delayed onset of mild cognitive impairment (MCI), and/or a lower incidence of AD [9-18]. These positive lifestyle factors may therefore be related to delayed $\mathrm{AD}$ onset and increase the resilience to develop AD.

On the other hand, adverse environmental experiences such as prolonged exposure to stressful experiences have been associated with a faster progression of $\mathrm{AD}$ symptoms and an earlier development of pathology [19, 20]. Stressful life events have been reported to reduce the age of onset in familial AD [19], while major depression, which has a strong stress-related component, has been associated with an increased risk to develop $\mathrm{AD}$ earlier in life (e.g. [19, 21]). Furthermore, glucocorticoid (GC) hormones, the main mediators of the stress response, are often found to be increased in $\mathrm{AD}$, notably already in early phases of the disease [22-26]. Finally, dysregulation of the hypothalamus-pituitary-adrenal (HPA) axis (i.e. the main neuroendocrine axis controlling GC release and feedback) may increase the risk to develop AD [21, 23, 27]. Together, these studies highlight a possible interaction between genetic predisposition and lifestyle factors such as stress and/or low socio-economic status in determining the vulnerability and resilience to develop AD.

In a recent study, Wang et al. [28] have identified the early life period (up until adolescence) in humans as a sensitive time window during which environmental factors can exert pronounced and lasting effects on the risk to develop AD. During this sensitive time window early in life, the brain is showing enormous growth and development. This period of postnatal development is also very sensitive to environmental factors that may interfere with the ongoing development of brain structure and function, and can thereby program brain function for life [29-36]. Indeed, stressful and traumatic experiences during the early life period have been strongly associated with an increased vulnerability to stressors, and compromised physical and mental health in later life, both in humans and rodents [29, 31, 37-40]. On the other hand, 'positive' or stimulating early life experiences in humans [28] and rodents [41] have been associated with an apparent resilience to later-life challenges and a better physical and mental health.

Here, we discuss recent literature on the role of early life experiences in driving AD pathology. While human studies underscore the clinical and societal relevance of this topic, we focus on animal studies. Such studies allow for examining causal relationships, underlying molecular and cellular mechanisms, and a better understanding of how early life experiences and genes interact to determine the vulnerability to develop $\mathrm{AD}$ pathology. The findings are discussed in the context of theories on 'cognitive reserve' and 'brain reserve' (see Box 1), which help to conceptualise why some individuals may be more prone to develop $\mathrm{AD}$ than others. Finally, we identify possible molecular mediators and define critical outstanding questions that will help improve our understanding of how the early postnatal period can modify the risk to develop Alzheimer's disease.

\section{Methods}

We review literature and discuss the role of early life experiences in determining later age and AD-related processes from a brain and cognitive 'reserve' perspective. We focus on rodent studies and the identification of possible early determinants of later $\mathrm{AD}$ vulnerability or resilience in relation to early life adversity/enrichment.

\section{Results \\ Early life experiences affect AD neuropathology and cognition \\ Early life adversity and $A D$}

Genetically modified mice allow for the modelling of specific pathological features of $\mathrm{AD}$ such as $\mathrm{A} \beta$ and tau pathology (see Box 2 for an overview). Many studies in these mice have demonstrated effects of early life experiences on later cognitive function (see Box 3 for an overview of animal models of early life experiences). In the widely used APPswe/PS1dE9 mice, cognitive performance at an adult age was generally impaired when the mice had been exposed to prenatal or early life stress. For instance, exposing these mice to repeated brief 


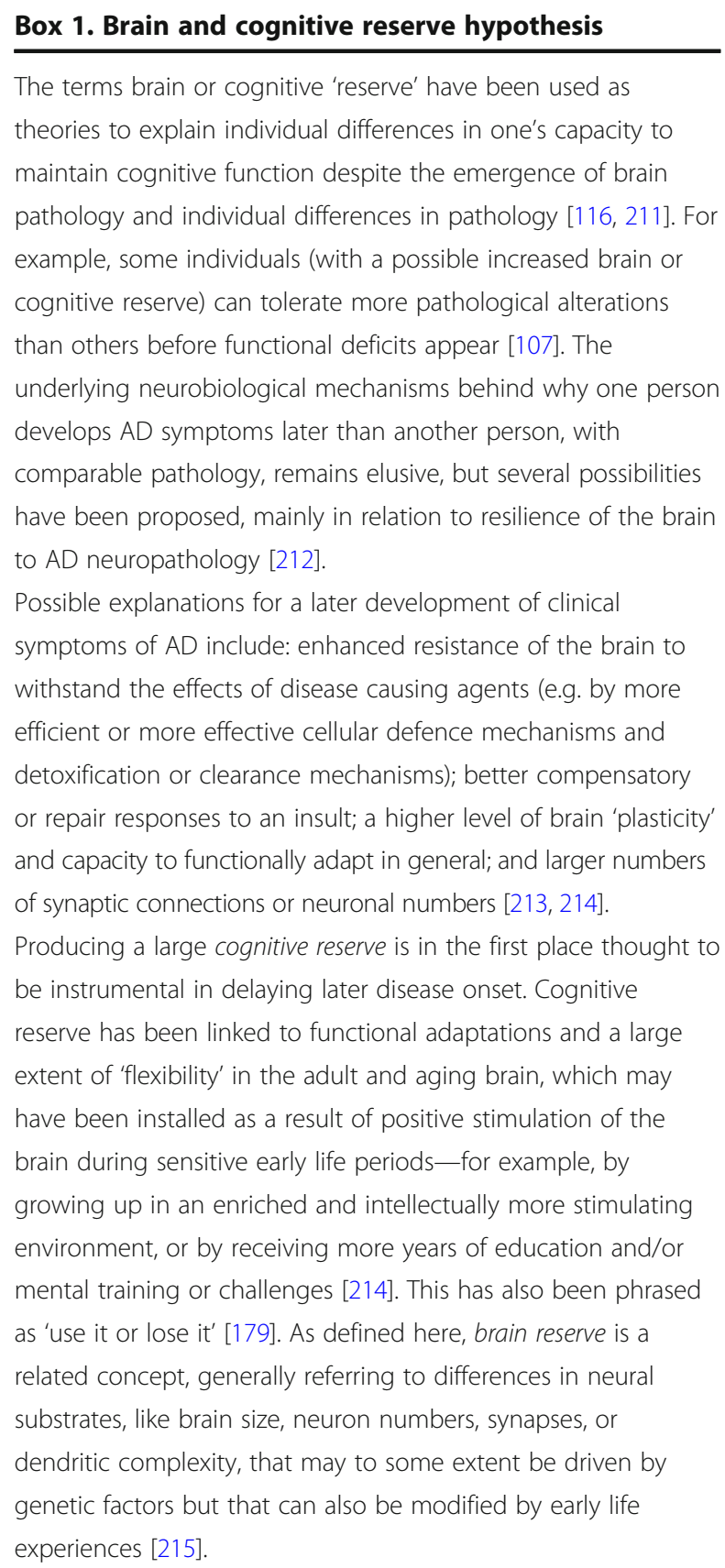

periods of restraint stress from embryonic day 1 to 7 resulted in impairments in object location memory at 6 months of age [42]. In addition, maternal separation attenuated spatial learning in the offspring as tested in the Morris water maze task in 9-month-old mice [43]. Furthermore, APPswe/PS1dE9 mice exposed to chronic early life stress from PND 2 to 9 displayed cognitive impairments 1 year later, specifically in cognitive flexibility [44]. These latter effects were not caused by early life stress alone, since wild-type mice exposed to early life stress were not impaired. This suggests that early life stress may accelerate and/or aggravate symptom development [44].

These cognitive impairments are often accompanied by alterations in $A \beta$ neuropathology. In middle-aged APPswe/PS1dE9 mice, both the plaque load and the soluble intracellular $A \beta$ levels were increased following early life stress exposure [43-45], although at 4 months of age also a decrease in cell-associated $A \beta$ has been reported after early life stress [45]. Counterintuitively, exposure to prenatal restraint stress reduced the plaque load in the hippocampus of 7-month-old female APPswe/ PS1dE9 mice when compared to control-reared female transgenic mice, while no effects were found on intracellular $\mathrm{A} \beta$ immunoreactivity [42]. These effects were also not observed in male offspring, which remained unaffected by prenatal stress exposure. Effects of early life adversity on later $\mathrm{AD}$ measures have been studied in other transgenic mouse models as well. For instance, in a model co-expressing mutant APP and tau (biAT-mice), chronic early life stress increased soluble $A \beta$ levels already in 4-month-old mice and reduced life expectancy [46]. This illustrates that in a genetic background relevant for $\mathrm{AD}$, additional exposure to early life stress can increase $A \beta$ neuropathology prior to the onset of cognitive impairments and even affect life expectancy.

Interestingly, the effects of stress early in life on both later cognition and AD-related neuropathology might not be specific for transgenic animals. In wild-type rodents, impairments in cognition occur following maternal separation, and are accompanied by increased levels of $A \beta 40$ and $A \beta 42$, an exacerbation of $A \beta$ pathology [47], $B A C E$ expression [48], and/or tau phosphorylation [47, 4953]. While in wild-type animals the $A \beta$ monomers do not aggregate into $A \beta$ plaques, these findings suggest that, regardless of the genetic background of an animal, stress exposure, be it early or later in life, promotes APP processing towards the production of more amyloidogenic species, and may thereby modify the sensitivity to develop AD pathology later in life.

\section{Early life enrichment and $A D$}

Although less well studied, exposing mice to an enriched and 'positive' environment during the early life period exerts opposite effects on cognition and AD-related neuropathology compared to early life stress [41, 46, 54]. For instance, neonatal handling, twice daily from PND 1 to 21 , which has been associated with enhancing levels of maternal care, prevented spatial cognitive deficits and emotional alterations at 4 months of age in $3 \times \mathrm{Tg}-\mathrm{AD}$ mice, an effect that was most pronounced in females [54]. Similarly, daily handling from PND 2 to 9 prevented the cognitive impairments in APPswe/PS1dE9 mice at 11 months of age [41]. Interestingly, while deficits in hippocampus-dependent and prefrontal cortex 


\section{Box 2. Rodent models of AD neuropathology}

Preclinical studies have employed transgenic and non-transgenic approaches to model aspects of Alzheimer's disease. These models generally reproduce various disease aspects: memory impairments, A $\beta$-containing plaques and/or tau/tangles, and neuronal loss (only in a few Aß-based models).

Transgenic models most frequently (over)express single or multiple mutations in the APP, presenilin (PS), and/or tau genes, or combinations of these genes, that relate to familial forms of AD. Non-transgenic models are generated by the injection of specific toxins into the brain, such as $A \beta$, tau, or inflammatory-related compounds, or use naturalistic models of aging. Although none of these models fully captures the entire human disease profile and they often model only one specific aspect of AD neuropathology, the existing models have made important contributions to our current understanding of AD pathophysiology. There are, however, distinct differences in the presentation of neuropathology in transgenic models and the human presentation of dementia, in particular with regard to animal models of amyloid pathology which overall display severe hippocampal amyloidosis, which is different from the human presentation of plaque pathology. Also, no tau mutations have been identified that cause autosomal dominant AD, unlike mutations in $A \beta$-associated genes. The $A \beta$ and tau-based models will be discussed here in more detail.

$A \beta$ neuropathology. The amyloidogenic pathway of amyloid precursor protein (APP) processing occurs through APP cleavage by $\beta$ and $\gamma$-secretases, producing C83, C99, and A $\beta$ fragments. A $\beta$ peptides can aggregate to form oligomers, which exist in different forms (e.g. soluble/insoluble, oligomeric, fibrillary plaques) and have different pathogenic properties. The most commonly used mouse models overexpress a mutant form of APP (isoform 695) with the Swedish mutation (KM670/671NL) ('Tg2576' mice), resulting in elevated levels of $A \beta$ and cognitive impairments by 1 year of age [216]. The introduction of an additional PSEN1 mutation, which increases $\gamma$-secretase activity, yields the widely used APPswe/PS1dE9 mouse, which develops progressive A $\beta$ deposits and cognitive impairments as early as 6 months $[217,218]$.

Tau neuropathology. Tau proteins are the product of the microtubule-associated protein tau (MAPT) gene, and mutations in this gene lead to hyperphosphorylated Tau. Excessive levels of this protein, or its abnormal phosphorylation, both result in the formation of NFTs and pathogenic paired-helical filament tau. The PS19 [219], Tau.P301L [220], and JNPL3 [221] models overexpress the MAPTP301L gene, and show progressive tangle-like pathology in the midbrain and brain stem, parallel to cognitive deficits (not reported in JNPL3 mice). Given the preferential targeting of the disease gene to these brain regions and the important role of tau for (large) motor neurons, many tau mutant mice develop motor problems prior to the onset of hippocampal and cognitive impairments, which is a drawback of these models.

Combined neuropathology. When multiple transgenes are combined, both $A \beta$ and tau neuropathology is induced, for instance in the bi-genic model overexpression APPV717I and Tau.P301L mutation ('biAT') [222]. Other commonly used models are the 3xTg-AD, harbouring the APP Swedish, the MAPT P301L, as well as the PSEN1 M146 V mutations, displaying learning deficits from 6 months onwards [223]. The 5xFAD model, harbouring the APP Swedish, Florida, and London mutations, as well as the PSEN1 M146 V and PSEN1 L286 V mutations show aggressive and early presentation of amyloid pathology, starting at 1.5 months of age [224]. Additional and related models have also been generated [226, 227].

(PFC)-dependent memory performance were prevented by the neonatal handling procedure in this study, amygdala-dependent memories were not affected [41]. In line with this, neonatal handling reduced the $A \beta$ plaque load in the hippocampus, but not in the amygdala [41]. Finally, in 4-month-old biAT mice, neonatal handling reduced $A \beta$ levels prior to the emergence of cognitive deficits, and prolonged life expectancy [46].

Together, these studies indicate that neonatal handling reduces or delays the incidence of $\mathrm{AD}$-related pathology, although differential effects on hippocampal and amygdala function were reported. Possibly, the developmental time window during which environmental manipulations are applied may have different outcomes. So far, it remains elusive what defines the optimal time window for installing lasting protective effects, an area of research that deserves more attention. In addition to the effects of positive stimuli during the early life period there are other studies showing protective effects of environmental stimuli, such as housing mice in enriched environmental conditions or exercise at adult or late age, on cognitive or neuropathological measures in different $\mathrm{AD}$ models.

\section{Conclusion: Early life experiences modulate $A D$ neuropathology and cognition}

There is substantial evidence from transgenic rodent studies which supports the concept that the perinatal environment determines the vulnerability or resilience 


\section{Box 3. Rodent models of early life stress and enhancement}

In the early life period, the brain shows massive development and is highly sensitive to environmental factors that can disturb this process and affect brain function for life. The effects of environmental factors depend on the maturity of the brain at the moment of intervention.

In animal models, the critical components shaping the local environment are the intrauterine environment (that can be affected by specific medication or, for example, stress hormones that reach the pregnant dam and her fetus(es)) and postnatal experiences. In rodents, the most relevant factor during the early postnatal period involves interaction between the dam and her offspring. This includes elements like tactile stimulation, nutrition, and warmth. Both prenatal and postnatal time windows can be manipulated experimentally to study the consequences of early life experiences.

First, models are used in which the naturally occurring variation in maternal care is used to select for pups that received high amounts of maternal care compared to pups receiving low amounts of maternal care (low vs high licking and grooming). This represents a model to test the consequences of 'negative' and stressful versus a 'positive' early life environment for later brain structure and function [139, 229].

Prenatal stress [211] encompasses stress induced in pregnant rodents by a single or repeated session of maternal restraint stress and/or defeat during specific gestational periods (mostly during the last week of gestation, sometimes earlier).

Alterations in the postnatal mother-pup interaction can also be induced experimentally. Postnatally, early life stress is, for example, induced by a single, prolonged separation of dam and pups (maternal deprivation [142]), which usually lasts for $24 \mathrm{~h}$ and is conducted at postnatal day (PND) 3 or 4 . Alternatively, maternal separation [230] involves separation of the dam and pups repeatedly for 2-5 h/day. Chronic early life stress [231] involves a reduction in the available nesting and bedding material, which triggers erratic and fragmented maternal care and stress in the dam which is transmitted to her offspring. In contrast, a 'positive' early life environment is typically installed by separating the dam and her pups for a brief period of up to 15 min on a daily basis, during a time window from PND 2 to 9 or until weaning. This model is generally called postnatal or neonatal handling [232-234] and results in increased levels of maternal care of the dam towards her pups upon reunion. for AD-related cognitive impairments and $\mathrm{A} \beta$ neuropathology later in life. Early life adversity generally worsens cognitive performance and aggravates $A \beta$ neuropathology, while early life enrichment can delay these cognitive deficits, at least for some behavioural domains, and attenuates $\mathrm{A} \beta$ neuropathology.

\section{Direct pathways}

There are multiple pathways that can mediate the effects of early life experiences on cognition and AD neuropathology. First of all, there are pathways that are affected by early life experiences, and that are known to directly affect either the production or clearance of $A \beta$. The steady-state levels of $A \beta$ depend on a balance between APP processing, the rate of $A \beta$ production, and clearance of the peptide from the brain [55]. Likewise, tau hyper-phosphorylation can also be potentiated by factors induced early in life.

\section{Hypothalamus-pituitary-adrenal axis}

The hypothalamus-pituitary-adrenal (HPA) axis controls circulating glucocorticoid hormones (cortisol in humans, corticosterone in rodents). In response to corticotrophin releasing hormone $(\mathrm{CRH})$, the pituitary releases adrenocorticotropin hormone $(\mathrm{ACTH})$, which in turn stimulates the release of glucocorticoid hormones from the adrenal cortex [56]. At the early stages of $\mathrm{AD}$, basal levels of circulating cortisol are often elevated [26, 57-59]. AD and dementia patients also show a failure to suppress their endogenous cortisol after administration of the synthetic glucocorticoid dexamethasone [25, 60, 61], indicating a dysfunction in the feedback of the HPA axis. Elevated basal cerebrospinal fluid (CSF) cortisol levels were specifically found in MCI patients who later developed AD, but not in MCI patients with other underlying neuropathologies. Moreover, higher baseline CSF cortisol levels were associated with a faster clinical worsening and cognitive decline in the MCI patients who were developing AD [62]. However, HPA dysfunction does not seem to worsen any further as the disease progresses [63, 64], suggesting that early life-induced alterations in HPA axis function, possibly acting via glucocorticoids, may in particular contribute to the onset and acceleration of $\mathrm{AD}$ pathogenesis, after which a new balance in HPA axis activity is reached. Rodent studies further indicate that pharmacological treatment with (synthetic) glucocorticoids or repeated stress exposure can induce pathological processing of both $A \beta$ and tau. Both stress-level glucocorticoid administration in $3 x \mathrm{Tg}-\mathrm{AD}$ mice [65] and stress induction in wild-type rats [66] increase the levels of APP and the $\beta$-APP cleaving enzyme 1 (BACE1), which in turn increases amyloidogenic processing of APP and results in elevated levels of APP-derived fragments (C99 and C83) and $\mathrm{A} \beta$ peptides. 
The early life postnatal environment is a strong determinant of HPA axis activity and later-life sensitivity to stressors [67]. In rodents, positive early life experiences generally dampen HPA axis reactivity, resulting in lower $\mathrm{CRH}$ and glucocorticoid levels in response to a stressor, whereas early life adversity generally increases HPA axis reactivity $[67,68]$. As a consequence, the subsequent, cumulative exposure to glucocorticoids and/or CRH in adult animals is often persistently enhanced by early life stress. The notion that elevated glucocorticoid levels can promote $A \beta$ levels (see earlier) may point to a critical role for these hormones in moderating AD neuropathology after early life adversity [65, 69, 70].

This points to the possible involvement of glucocorticoids in the initial development, or later promotion, of $\mathrm{AD}$ neuropathology, rather than that the alterations in glucocorticoids observed in AD may result from disease progression. However, prolonged glucocorticoid exposure, or exposure after early life stress, most likely cannot fully account for the neuropathological effects observed. Following chronic early life stress, wild-type animals show decreased corticosterone levels in response to an acute stressor, whereas APPswe/PS1dE9 mice exposed to the same paradigm, but not control-reared AD mice, display elevated corticosterone levels [44]. Thus, AD neuropathology by itself can also affect HPA axis functioning, which may depend on disease severity.

Notably, early life stress also increases the expression of BACE1 in adult wild-type mice [47, 71, 72] and APPswe/ PS1dE9 mice [44]. The enhanced BACE1 expression following early life or adult stress exposure can be a direct effect of altered glucocorticoid signalling, as BACE1 contains glucocorticoid binding sites [73]. Indeed, short-lasting treatment with the glucocorticoid receptor antagonist mifepristone rescued the early life stress-induced cognitive impairments in APPswe/PS1dE9 mice and reduced the $\mathrm{A} \beta$ load and BACE1 expression [44]. In addition, a reduction in APP-derived C99 and C83 fragments was reported in 3xTg-AD mice after a similar treatment [74]. This suggests that the same pathway was affected by both manipulations and hence that APP processing is specifically targeted by (anti)-glucocorticoid actions. Alternatively, it has also been suggested that epigenetic modifications are responsible for the enhanced BACE1 expression [75].

Besides glucocorticoids, other stress mediators (such as $\mathrm{CRH}$ ) have also been implicated in AD-related neuropathology. AD patients display reduced levels of $\mathrm{CRH}$ in the cortex and CSF [76, 77]. Rodent studies have further identified a role for $\mathrm{CRH}$ in protecting neurons against A $\beta$-associated cell death [78], possibly by promoting non-amyloidogenic APP cleavage $[79,80]$. In contrast to these findings is the observation that stress exposure elevated $\mathrm{CRH}$ levels as well as $A \beta$ expression [81, 82]. The role of $\mathrm{CRH}$ in $\mathrm{A} \beta$ pathology therefore needs further investigation.

Although less extensively described in recent literature, chronic stress or glucocorticoid exposure also induces abnormal hyper-phosphorylation of tau in wild-type mice [50] and 3xTg-AD mice [65]. Glucocorticoids potentiate the ability of centrally infused $\mathrm{A} \beta$ to induce hyper-phosphorylation of tau epitopes associated with AD [50], suggesting that tau pathology is also affected by HPA axis-related mechanisms [83, 84]. Although speculative, this could be a mechanism by which early life experiences, via alterations in HPA axis activity, could modulate tau pathology. Together, these studies highlight the potential of alterations in glucocorticoids and $\mathrm{CRH}$, both factors affected by early life experiences, to be involved in promoting $\mathrm{AD}$ pathology, and that modulating these systems may directly affect pathological markers such as $A \beta$ production and tau hyperphosphorylation. However, further research is warranted to understand the exact mechanisms how this occurs, and the causative nature of the effects, in particular regarding tau pathology.

\section{Blood-brain barrier integrity}

$\mathrm{A} \beta$ in the brain is controlled via a steady-state homeostatic balance of production and removal. In humans, approximately $25 \%$ of $A \beta$ is cleared from the brain via the blood-brain barrier (BBB) [85]. Post-mortem studies have shown that BBB integrity declines with age [86, 87], and might be involved in the onset of dementia [88]. Both acute and chronic activations of the stress system may compromise the permeability of the blood-brain barrier $[89,90]$. Restraint stress in rodents induces damage in the capillary brain endothelial cells and alters expression of the tight-junction proteins occludin, claudin-5, and glucose transporter- 1 in these brain capillaries, pointing to impaired BBB functioning [90]. Interestingly, mice that are resistant to the induction of a depression-like phenotype after exposure to chronic social defeat stress (CSDS) showed an upregulation of claudin-5 levels and more intact brain endothelial cell morphology compared to mice sensitive to CSDS [89]. Although further experimental validation is required, particularly with regard to how early life experiences regulate BBB stability and permeability for life, (early) stress could possibly influence $A \beta$ clearance from the brain through altering the permeability of the BBB.

\section{Neuroinflammation}

Another mechanism possibly involved in the clearance of $A \beta$ from the brain is via the brain's neuroinflammatory response. For example, microglia bind $A \beta$ oligomers and fibrils and clear $A \beta$ from the brain through the secretion of $\mathrm{A} \beta$-degrading enzymes like neprilysin [91] and 
insulin-degrading enzyme (IDE) [92], and through the phagocytic uptake and active degradation of $A \beta$. Both IDE and neprilysin activities are reduced in $A D$, and, interestingly, are further inhibited by glucocorticoids [93]. In response to $A \beta$ oligomers, microglia induce an acute inflammatory response to aid clearance and restore homeostasis [94-96]. In the prolonged presence of $\mathrm{A} \beta$ accumulation, however, the physiological functions of microglia, such as synaptic remodelling, are thought to be compromised and may lead to a chronic neuroinflammatory response [97]. This progressive microglial activation, elevated pro-inflammatory cytokine levels, and morphological changes of microglia may result in functional and structural alterations that ultimately can promote neuronal degeneration [97]. Adverse early life experiences have been reported to alter the number of microglial cells, their morphology, phagocytic activity, and gene expression in the developing hippocampus that extend into the juvenile period (reviewed in [98-100]). These changes in microglial function are associated with abnormalities in developmental processes known to be mediated by microglia, including synaptogenesis, synaptic pruning, axonal growth, and myelination (reviewed in $[100,101])$, and make them more responsive to subsequent inflammatory challenges like $A \beta$ (microglial 'priming') [99, 102-104]. Conversely, neonatal handling programmes the expression of the anti-inflammatory cytokine IL-10 early in development by decreasing its methylation within microglia, attenuating glial activation [105]. Recently, exposure to early life stress in APPswe/PS1dE9 mice was shown to increase the plaque load while attenuating microglial responses in a lasting manner [45]. Whether enhanced $A \beta$ pathology reduces microglial response, or whether early life programming is truly causing alterations in microglial activation, which in turn may modulate $A \beta$ neuropathology, requires further investigation.

Thus, impairments in glial functioning and/or in the inflammatory response to $A \beta$, possibly modulated or 'primed' by early life experiences, could lead to an altered $A \beta$ phagocytic capacity or clearance, and hence an altered $A \beta$ burden with increasing age. Further studies are required, both with regard to whether positive early life experiences increase $\mathrm{AD}$ resilience via the modulation of such neuroinflammatory responses, and regarding the extent to which, and how, early life events can indeed programme microglia directly and indirectly.

\section{Modulation of $A D$ resilience/vulnerability through altered cognitive and brain reserve following early life experiences}

Besides a direct modulatory role of early life experiences on $\mathrm{AD}$ neuropathology and related cognitive decline (i.e. via regulation of $A \beta$ and tau), early life experiences may also modify the brain's ability to cope with the pathological burden of AD. For instance, a healthier, more active, and more flexible brain may have a higher capacity to 'circumvent' or delay effects of an insult and hence cope in a better way with the challenges posed by the $\mathrm{AD}$ pathology [106]. This concept has been termed 'brain reserve' or 'cognitive reserve', and has been introduced to explain individual variation in vulnerability and resilience for age-related cognitive decline (see Box 1). These concepts stem from findings that brain pathology (such as plaque load) is an unreliable predictor of human cognitive performance given that, with a comparable pathological load, some patients perform better than others in cognitive tasks [107]. This could be a secondary mechanism, in addition to the mechanisms already described, through which early life experiences determine behavioural $\mathrm{AD}$ outcome.

\section{Early life experiences, brain reserve, and cognitive reserve}

The hypothesis that early life experiences influence brain or cognitive reserve, and may either protect against or aggravate the clinical consequences of $\mathrm{AD}$ neuropathology, comes from several epidemiological studies. For instance, individuals with less than 8 years of formal education had a 2.2 times higher risk of developing dementia than those with more than 8 years of education, and participants with low socio-economic status were at 2.25 times greater risk of developing dementia than those with high lifetime occupational attainment [108]. Conversely, higher education and higher social economic family status reduced the risk of dementia lastingly [28], while both the number of years of formal education [109] and higher school grades appear to protect against dementia, even in the absence of later-life educational or occupational stimulation [110]. Furthermore, elderly people participating in frequent leisure activities expressed a 38\% lower risk of developing dementia [111]. Also, early life linguistic ability is a strong predictor for later-life cognitive performance and being raised in a bilingual family, for example, protects against AD [16, 112]. Conversely, the occurrence of a parental death between age 0 and 18 is associated with a higher incidence of AD [113]. Such associations between early life environmental factors and $\mathrm{AD}$ indicate that cognitive stimulation at an age at which the brain is still in development may contribute to the building of cognitive reserve and thereby reduce the risk for later $\mathrm{AD}$, while disturbances like stress or trauma during early life can be detrimental for building cognitive reserve. This is consistent with observations in animal studies demonstrating the existence of specific 'critical periods' during early life $[114,115]$ when disturbances in neuroplasticity can have a long-lasting impact on brain function. Overall, these studies indicate that educational and possibly also specific occupational 
experiences may create a reserve that could delay effects of $\mathrm{AD}$ pathology. This does not exclude the important contribution of the genetic background nor of familial and societal factors that may also promote a higher educational and occupational stimulation and thereby a better coping with pathological load at later ages.

Although patients with high education/socio-economic status show a delayed onset of AD symptoms, they typically show a more rapid cognitive decline once the disease starts [116, 117]. This may suggest that patients with a high reserve can tolerate a higher burden of $A D$ pathology in the brain, and that the time point at which cognitive functions begin to become affected will be later than in those with a lower cognitive reserve (Fig. 1). However, in all people, eventually a common point is reached when the pathology is so severe that brain function cannot be maintained anymore. Individuals with the greatest cognitive reserve will have a more advanced pathology at the onset of cognitive decline, although there will be less time until they reach the point when pathology overwhelms function, and then a more rapid rate of decline is expected [118] (Fig. 1).

Despite the support for this theory from epidemiological studies, more controlled studies aimed to determine whether (early) environmental factors can actually help build $\mathrm{AD}$ resilience are thus far lacking. In particular, the question remains open which molecular and cellular substrates mediate the effects of life experiences, especially those occurring early in life, on cognitive reserve and clinical AD outcome.

\section{Animal research of early life experiences and cognitive reserve}

Although attractive as a concept, it is currently unknown which brain mechanisms underlie brain and cognitive reserve. To address this, animal studies are required to address how a brain and cognitive reserve can be installed, and what the underlying molecular and cellular substrates are.

One possible mechanism for a cognitive reserve is the ability/capacity to compensate for dysfunction in one brain circuit by recruiting associated, unaffected brain circuitries, at least functionally. This would allow for switching between cognitive strategies and for using alternative and/or additional brain networks, to better cope with $A \beta$ pathology. For instance, Granger et al. [119] observed that male and female mice overexpressing the human APP transgene exhibited similar neuropathological load. However, females displayed earlier cognitive impairments than males, which were able to

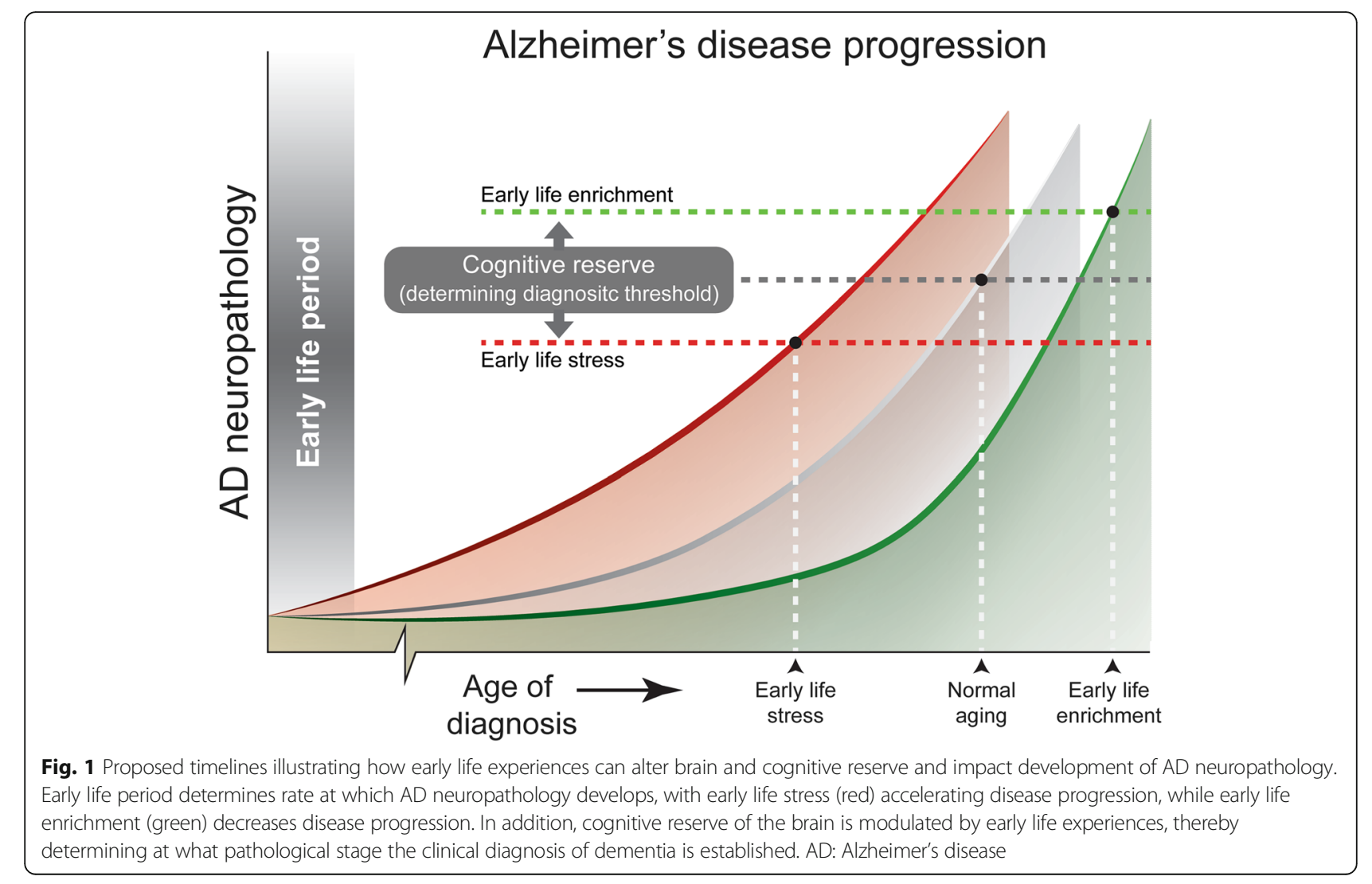


compensate for $\mathrm{A} \beta$-associated impairments by alternating navigational search strategies and by adopting increasingly productive spatial search strategies in the Morris water maze task. In contrast, females failed to efficiently switch from systematic to spatial learning strategies, potentially indicating a weaker cognitive reserve [119]. In addition, there is evidence that (early life) stress affects cognitive reserve. When presented with a dual-solution spatial navigation task, in which two different strategies can be employed to solve the task, both humans and mice, under a low stress condition, primarily use a hippocampus-dependent spatial strategy. However, when presented with a stressor prior to the task, they switch to a striatum-dependent stimulus-response strategy [120-125]. Likewise, prenatal and postnatal stress in rodents have been reported to bias navigation strategies towards more rigid, inflexible striatum-based learning strategies even under low stress conditions [126-128]. This indicates that early life stress decreases cognitive flexibility and the ability to activate different brain areas. This capacity for recruiting alternative strategies and related brain networks to solve problems has not been studied in relation to early life experiences and AD (although APPswe/PS1dE9 mice exposed to chronic early life stress show impaired behavioural flexibility, as measured by reversal learning on the Barnes maze [44]).

\section{Mediators of early life experiences and brain reserve}

Animal models have been used for detailed assessment of how early life experiences can affect components that may underlie brain reserve. This involves dendritic morphology, spine number, synaptic plasticity, and proteins that regulate synaptic function, which all determine plasticity of the brain and may render the brain more or less susceptible for AD-related pathological changes.

Dendritic morphology Various studies have shown that prenatal and neonatal experiences cause persistent morphological changes in specific limbic brain regions and PFC [129-133]. For example, following early life stress, dendritic atrophy of CA1 pyramidal cells and expansions in the CA3 mossy fibres were observed, while the number of granule cells and the dendritic complexity in the hippocampal CA1 area and its innervation of CA3 pyramidal neurons were reduced [134], possibly via stress-induced increased $\mathrm{CRH}$ levels [68]. Furthermore, exposure to chronic early life stress reduced the number of dendritic spines, the anatomical substrate for memory storage and synaptic transmission, in both CA1 and CA3 areas and reduced inhibitory synaptic density in the CA1 area and excitatory synaptic density in the CA1 and CA3 areas of the hippocampus [135]. Although less well described, other brain regions are also affected, and chronic early life stress hampered dendritic development and spine density in the
PFC $[135,136]$, while it increased spine density in the basolateral amygdala [137]. In addition, pups that received low amounts of maternal care early in life show reduced dendritic complexity in the CA1 area and dentate gyrus at adulthood, when, compared to pups that received high amounts of maternal care [34, 138, 139]. Also, the number of spines in hippocampal neurons was higher in pups that received high compared to low amounts of maternal care $[138,139]$. Finally, maternal separation caused atrophy of the basal dendritic tree and reduces spine density on both the apical and basal dendrites in layer II/III of the PFC [140], and maternal deprivation reduced the number of granule cells and dendritic complexity in the dentate gyrus $[141,142]$, but had no effects in the amygdala [143]. These studies indicate that enhanced patterns of paternal sensitivity enhance dendritic complexity later in life in brain areas that are critical for learning and memory processes. This may therefore potentially affect cognitive function, synaptic plasticity (see below), and the cognitive reserve.

Synaptic plasticity Disturbances in LTP have been implicated in the early manifestation of AD $[144,145]$. Several in-vitro and in-vivo studies have directly implicated $\mathrm{A} \beta$ oligomers as a trigger of synaptic dysfunction (e.g. [146]), by weakening synapses, impairing LTP, and affecting the density of dendritic spines [145, 147-152]. Under conditions where LTP induction is already challenged-for example, following early life stress exposure $[68,134,135,138,139,142,153-157]$ - the effects of $A \beta$ on synapses and plasticity can be aggravated, thereby accelerating the onset of cognitive impairments. In contrast, when enhanced LTP is formed as a consequence of early life enrichment, the effects of $A \beta$ can be alleviated, delaying the onset of cognitive impairments. As $A \beta$ specifically targets synapses and disrupts synaptic signalling pathways, a larger or smaller dendritic tree and/or spine density could provide a structural substrate that could modulate effects of the first exposure to $A \beta$, and hence make specific synapses more or less vulnerable to $\mathrm{A} \beta$-induced neuronal death. Together, alterations in synaptic plasticity, evoked by early life experiences, could influence the adult brain's capacity to 'circumvent' $\mathrm{AD}$-associated insults for a longer time, thus prolonging the period of healthy cognitive performance despite ongoing $A \beta$ neuropathology.

Repressor element-1 silencing transcription factor (REST) Recent studies have indicated how early life experiences can affect synaptic functions. For instance, during development there is a switch in NMDA-R composition, with GluN2B being predominantly present in the early postnatal brain. Over time, the number of GluN2A subunits increases, and after 2 weeks they outnumber the GluN2B [158]. This process can be disturbed 
by early life stress, as maternal deprivation slows down the switch to a mature, predominantly GluN2A-containing NMDA receptor phenotype at PND 28 to 31 [159]. Interestingly, by 8 weeks of age, the effects of early life stress on the GluN2B-GluN2A switch were reversed with more GluN2B expression in the hippocampus [156]. This disturbed developmental switch has been suggested to be mediated by an impaired activity of the transcriptional repressor REST in the hippocampus following early adversity [159]. REST is a gene-silencing factor expressed during development that inactivates neuronal genes important for synaptic functioning, among which is the gene encoding GluN2B, and is essential for the experience-dependent fine-tuning of gene expression involved in synaptic activity and plasticity $[160,161]$. The composition of the NMDA receptor is of particular relevance as $A \beta$ acts specifically via the GluN2B subunit, effecting a switch in subunit composition from GluN2B to GluN2A [162]. REST has been found to be present during normal aging of cortical and hippocampal cells but to be lost in both MCI and AD. Also, REST switches off genes promoting cell death while promoting the expression of various genes involved in the protection against stress [163]. Cognitively healthy elderly people indeed show increased REST levels compared to cognitively impaired elderly people. This makes REST an interesting candidate that could link early life experiences to later resilience to $\mathrm{AD}$. However, whether changes in REST expression following early life experiences persist into aging remains to be further investigated.

Early growth response protein 1 (EGR1) Another candidate to mediate effects of early life experiences on AD vulnerability/resilience is EGR1 (also commonly referred to as Zif268, NGFI-A, or KROX-24), a transcription factor critically involved in processes underlying neuronal activity, from neurotransmission and synaptic plasticity to higher order processes such as learning and memory, and to the response to emotional stress and reward [164-169]. EGR1 expression is induced in neurons by activity-dependent synaptic plasticity upon learning. Both the complete absence of and the heterozygous deletion of EGR1 are associated with impaired LTP maintenance over longer periods of time [170]. In contrast, EGR1 overexpression enhances LTP [171]. There is also extensive evidence that EGR1 expression is sensitive to natural environmental stimuli, such as learning tasks $[172,173]$, and learning-related increases in EGR1 expression have been reported in many paradigms and brain structures (e.g. [174, 175]).

EGR1 is expressed at low levels during the postnatal period. Over a period of about 2 weeks (for the hippocampus), expression levels slowly increase to reach adult levels [169]. Interestingly, neonatal handling increased EGR1 mRNA and protein levels [176], while postnatal restraint stress downregulated EGR1 [177]. Furthermore, early life stress induces rapid alterations in the acetylation of histones $\mathrm{H} 3$ and $\mathrm{H} 4$, which correlate with the expression of EGR1, and stress-induced activation of the GR itself also regulates EGR1 expression [178]. This highlights a role for EGR1 as an experience-dependent mediator of the adaptation to different early environments. It is tempting to speculate that the altered expression of EGR1, usually measured acutely after the early life period, may be a starting point for the long-term dendritic and synaptic reorganisation following these experiences.

EGR1 expression is of particular interest in shaping brain reserve in $\mathrm{AD}$, as it is upregulated during the non-symptomatic stages of $\mathrm{AD}$, but not in symptomatic stages in humans $[179,180]$, and is also downregulated in cognitively impaired aged mice $[181,182]$. The effects of EGR1 may counteract A $\beta$-mediated synaptotoxicity; in patients who show AD pathology but do not have cognitive decline (Braak stages II-III), EGR1 may be upregulated to increase synaptic plasticity as an attempt to compensate for $A \beta$-induced neuropathology. After a certain threshold has been reached, EGR1 is no longer able to compensate sufficiently given the synaptotoxic consequences of $A \beta$, and cognitive impairment associated with the symptomatic stage of $\mathrm{AD}$ is thought to commence. Lower initial levels of EGR1 following early life adversity could thus result in a lower capacity to counteract, or 'deal with', $A \beta$ neurotoxicity and an earlier display of cognitive impairment, whereas higher baseline EGR1 expression following positive early life experiences would allow the brain to counteract $A \beta$ neurotoxicity for a longer period of time.

More recently, EGR1 has also been implicated as a driving factor of $\mathrm{AD}$ neuropathology and cognitive decline, since hippocampal EGR1 inhibition was shown to reduce tau phosphorylation, lower $A \beta$ pathology, and improve cognition in 3xTG-AD mice [183]. Since EGR1 inhibition was also shown to activate BACE1 activity [184], this calls for further studies into the role of (early life) modulation of EGR1 and its implication in cognitive impairment and AD neuropathology.

Activity regulated cytoskeleton-associated protein (Arc) Several potential target genes of EGR1 have been implicated in AD vulnerability, among which is the immediate-early gene Arc (also commonly referred to as Arg3.1), which is activated upon EGR1 expression $[185,186]$. Arc is critical for memory consolidation [187] and is abundantly expressed in dendrites [188], the postsynaptic density [188], and the nucleus [189]. 
Glutamatergic neurons in the brain express Arc following increased synaptic activity associated with a range of behavioural and learning paradigms [190]. This process is altered in AD (models) [191-194]. Arc has been implicated in the homeostatic scaling of synaptic strength [195] by selectively lowering the levels of AMPA receptors that contain subunit GluA3 [196]. GluA3-containing AMPA receptors, in contrast to those containing subunit GluA1, traffic to synapses independent of neuronal activity $[197,198]$. Thus, while active synapses are enriched for GluA1, synapses that are deprived of input are enriched for GluA3 [199]. Interestingly, the presence of GluA3 is required for $A \beta$ to mediate synaptic and memory deficits [145], suggesting that Arc and GluA3 expression may render synapses resistant to $A \beta$. Besides this protective role, Arc may also contribute to the pathogenesis of $\mathrm{AD}$ by regulating the neuronal production of $\mathrm{A} \beta$ [194].

Arc expression is regulated via activation of GRs [200, 201], the expression of which is affected by early life experiences. Indeed, lifelong Arc expression can be determined early in life, and Arc mRNA expression was, for example, strongly reduced in aged rats with a history of maternal separation [71]. Furthermore, Arc expression is reduced with aging per se in wild-type animals [71], possibly underlying impairments in cognitive performance with older age, and particularly in AD. For example, following learning experiences, Arc expression was lower in the neocortex of AD transgenic mice, indicating an impairment in neuronal encoding and network activation [202]. Increased levels of $A \beta$ in transgenic mice expressing human APP resulted in impaired Arc expression and hyperexcitable networks and the subsequent development of seizures [203, 204]. This suggests that increasing Arc levels prior to the development of $\mathrm{AD}$ neuropathology (e.g. through positive early life experiences) could possibly protect for a longer period of time against the cognitive impairments that accompany AD neuropathology.

\section{Conclusion: early life environment and cognitive/brain reserve}

Together, these findings highlight the programming role of early life experiences in specific measures reflecting brain and cognitive reserve. Dendritic morphology, spine density, synaptic protein expression, and the induction of LTP are all decreased/weakened following early life adversity, whereas a positive early life environment enhances/increases these parameters, resulting in later alterations in brain plasticity and behaviour. The installation of such alterations occurs prior to disease onset and can modify brain function at many levels. Consequently, these changes may determine the extent of reserve that the brain encompasses, and could determine its ability to later cope with further insults like the emergence of different aspects of AD neuropathology.

Experimental evidence for this hypothesis is thus far limited, and very few studies have addressed the effects of early life experiences on the aforementioned parameters in genetic AD models, while the preliminary studies published so far are not fully conclusive. Whether the molecular changes in, for example, REST, EGR1, and Arc expression following early life experiences indeed persist throughout the life span of an animal, and can thus actually affect the rate of aging, remains to be further investigated. A correct interpretation of the functional implications of the stress-induced or AD-induced upregulation or downregulation of some of these markers or processes underlying effects of early life experiences on cognitive reserve is further complex; the magnitude and direction of these neurochemical changes depend on a variety of factors, including the type and severity of the stressor, the age of the animal during stress exposure, and the age, sex, and species of the animal used upon testing, as well as the brain area and cell types studied. Further research is therefore needed to answer the question of whether the stress-induced upregulation or downregulation of a given process is beneficial or detrimental for neuronal and synaptic plasticity, and whether this may then mediate the potential to adapt brain and behaviour to a stressful or AD-related microenvironment before any clinical application of any of these targets can be implemented. In particular, carefully controlled, well-timed, and region-specific interventions on these targets in animal models should be performed before we can causally link them to AD resilience, let alone consider them as a target for human interventions.

\section{Discussion}

\section{Lessons from animal models of $A D$}

In animal models for $\mathrm{AD}$, early life experiences can have a profound impact on aging and survival, later cognitive function, and the development of $\mathrm{AD}$-specific neuropathological features. These effects are two-sided: directly by altering disease-modifying factors, and/or indirectly by affecting the brain's ability to cope with these insults. Early life experiences can determine the vulnerability or resilience to develop Alzheimer's disease (Fig. 2) by persistently altering systems involved in both $A \beta$ production and clearance. For instance, HPA axis hyperactivation after early life stress leads to $\mathrm{cu}$ mulative increased exposure to glucocorticoids, which can directly (potentially) promote amyloidogenic processing of APP, potentially impair BBB integrity, and affect the neuroimmune response. Together, this may reduce the brain's clearance ability and enhance accumulation of $A \beta$ in the brain. Conversely, early life 'enrichment' may lower lifelong glucocorticoid exposure 


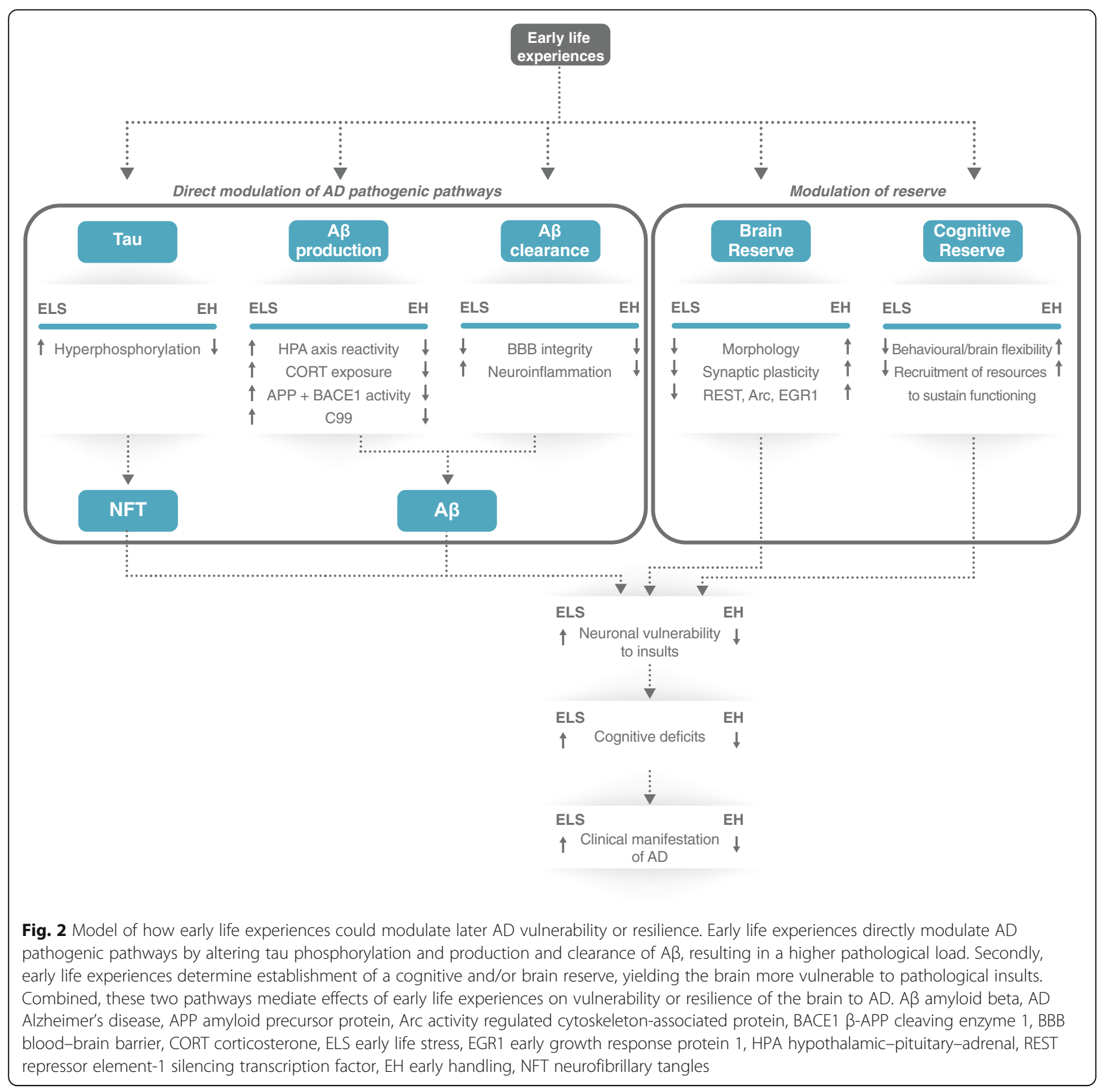

and counteract these effects. Besides a direct modulation of the amyloidogenic processing, early life experiences may also programme the ability of the brain to cope with AD pathology. Positive and stimulating early life experiences can further increase factors associated with brain reserve such as dendritic and spine architecture, synaptic plasticity, and proteins such as EGR1, REST, and Arc. Consequently, this may influence the ability of the brain to cope with AD-related neuropathological changes before cognitive deficits become apparent. Conversely, early life stress can reduce these factors, making the brain less capable to cope with AD-related pathological changes. Although not yet addressed in sufficient detail, animal models for early life stress are particularly suitable to identify the so far unknown key molecular and cellular mechanisms that underlie brain and cognitive reserve and the correlations between specific early life experiences and later AD risk.

\section{Clinical implications}

Identification of the factors that are causally related to $\mathrm{AD}$ resilience could be pivotal in individual risk assessment and determining disease vulnerability for aged individuals and MCI patients. In addition, these factors might aid the future development of early environmental and/or pharmacological interventions aimed to 


\section{Box 4. Outstanding questions}

\section{Rodent studies}

(1) How does early life adversity enhance the vulnerability to develop AD pathology?

Early life adversity regulates AD pathology later in life. Although there is evidence that the time of onset and/or severity is affected, an important question remains regarding which mechanisms are involved. This requires a deeper understanding of the role of environmental factors altering A $\beta$ production (e.g. early changes in HPA axis activity) and clearance (BBB, neuroimmune response), but also on molecular factors (REST, EGR1) that determine synaptic function and the sensitivity of synapses for $A \beta$.

(2) When is the brain most sensitive to factors that determine the later vulnerability to develop AD pathology?

Studies on early life adversity and AD have mostly focused on different prenatal and postnatal periods (until weaning), while effects of stress during adolescence and adulthood have also been reported. A critical question is what are the actual most critical time windows during which the brain is most sensitive for early life adversity and later sensitivity to develop AD pathology?

(3) Does early adversity affect cognitive reserve?

There are ample indications that early life stress affects brain reserve. However, whether and how early life adversity affects cognitive reserve remains to be determined in more detail. To this end, how cognitive reserved is defined neurobiologically and mechanistically is imperative in order to converge findings from the rodent and human literature. In particular, it is critical to understand the underlying neuronal networks, connections, and synaptic properties that mediate cognitive reserve. Behaviourally, it will be important to understand whether (and how) early life adversity affects learning strategies and behavioural flexibility in AD mouse models, as well as measures of cognitive reserve.

(4) Can the resistance of the brain to develop AD pathology be enhanced?

While the questions already mentioned focus on the consequences of early life adversity, it will be of equal importance to determine whether and how cognitive stimulation and/or early life enrichment can reduce the sensitivity for AD pathology. Is it possible to enhance neuronal activity and promote plasticity in relevant brain areas in order to delay AD-related neuropathology and cognitive decline? This includes studies on the developmental trajectories of AD pathology, its mechanisms, and sensitive time windows. In line with this, it will be important to investigate whether effects of early life adversity on the sensitivity to develop AD pathology can be prevented or normalised. This may involve factors such as exercise, cognitive stimulation, nutrition, and/or pharmaceutical intervention.

\section{Human studies}

(1) Do early life experiences affect AD in humans?

Rodent studies indicate a strong relationship between early life experiences and the development of AD pathology. It remains elusive whether such associations are also found in humans. Can existing human longitudinal cohort studies confirm the associations found preclinically between early life experiences, AD vulnerability/resilience, and alterations in brain function and cognition?

(2) What are the critical time windows for development of AD pathology?

Can critical time windows be identified in humans during which stress modifies AD risk? Which are the critical periods for early stress in humans, and can interventions during those periods indeed interfere with the effects of early adversity on later AD changes?

\section{(3) Is it possible to modify vulnerability for AD pathology?}

It will not only be important to understand whether and how effects of early life adversity can be overcome, but in general whether and how strategies recruited to increase the resistance for developing and delaying AD pathology can be optimised and implemented. Based on fundamental studies, this may involve strategies such as cognitive stimulation, exercise, and nutrition. 
increase $\mathrm{AD}$ resilience (see Box 4 for an overview of the remaining outstanding questions). However, we warrant caution in the (over)interpretation of the available preclinical findings and their relevance in the clinic since the fundamental basis of the described targets and their causal relevance to $\mathrm{AD}$ is not yet fully understood, and the gap between preclinical and clinical studies can be vast. To bridge this gap, further clinical validation of the concepts identified in rodent studies may yield insight into their relevance for patients. In particular, existing longitudinal cohort studies could help identify first hints as to whether early stress affects AD-related parameters, and from there could help to identify critical time windows during which cognitive reserve is most effectively established. Cohort studies in which people have been followed into older age and in which data have been collected throughout life are specifically suitable, as this allows examination of the association between early life factors and prevalence of MCI and dementia as well as pre-symptomatic markers. For example, studies in the Dutch famine birth cohort have shown that exposure to malnutrition in early gestation, a severe early life stressor, was associated with poorer cognitive function in subjects with the age of 58 years, as well as smaller brain volumes and increased symptoms of brain ageing in men at age 68 years [205-207]. Alternatively, this could be further simplified and cohorts stratified when reliable 'signatures' or biomarkers of early life stress could be developed and would be available, as is now done for adult stress exposure based on hair cortisol measurements [208]. Furthermore, some of the molecular targets highlighted in this study that mediate effects of early life experiences on reserve are also modulated by learning processes per se. Thus, pharmacological interventions using these targets in the clinic are still far away, as many of these targets need to be further validated first, also due to their versatile functions and the expected accompanying side-effects. Moreover, these target proteins may also be influenced using environmental stimuli at older ages.

One of the few interventions that have been shown to be successful in rodent studies at older ages and after a relatively short treatment, while also being FDA approved, is targeting glucocorticoid hormones [44, 74]. Also, a small clinical trial in AD patients and old macaque monkeys reported improvements in cognition after treatment with mifepristone (GR antagonist) [209, 210], although the short time window and small sample size warrant caution in interpreting these results. Furthermore, AD patients with the highest baseline cortisol levels benefited most from a mifepristone intervention and showed persistent memory improvements up to 8 weeks after discontinuation of the treatment [210]. This could therefore potentially present a promising strategy to further explore, specifically in stress-enhanced AD presentation.

\section{Conclusion}

The mechanisms identified through preclinical studies, supported by possible follow-up in validation studies to clinical pilot studies eventually, will hopefully benefit the identification and stratification of populations with higher vulnerability to develop $\mathrm{AD}$, as well as aid in the selection of putative targets. Ultimately, this may promote the development of an early and targeted treatment approach during the many decades between the early life environment and clinical $\mathrm{AD}$ presentation.

\section{Abbreviations \\ AD: Alzheimer's disease; ApoE4: Apolipoprotein E4; APP: Amyloid precursor protein; Arc: Activity regulated cytoskeleton-associated protein; $A B$ : Amyloid beta; BACE1: $\beta$-APP cleaving enzyme 1; BBB: Blood-brain barrier; biAT: Bigenic APPswe and Tau.P301L; CA1-3: Cornu ammonis 1-3; CRH: Corticotropin releasing hormone; CSDS: Chronic social defeat stress; EGR1: Early growth response protein 1; FAD: Familial Alzheimer's disease; GC: Glucocorticoid hormone; GR: Glucocorticoid receptor; HPA: Hypothalamic-pituitary-adrenal; IDE: Insulin- degrading enzyme; LTP: Long-term potentiation; MAPT: Microtubule-associated protein tau; MCl: Mild cognitive impairment; NFT: Neurofibrillary tangle; PFC: Prefrontal cortex; PND: Postnatal day; PS: Presenilin; REST: Repressor element- 1 silencing transcription factor}

\section{Funding}

PJL, HJK, and SLL are supported by Alzheimer Nederland (grant \#12354). The funding body had no influence on the design of the study.

\section{Authors' contributions}

SLL and HJK designed the study. SLL, LH, AK, SRdR, DFS, HWK, PJL, and HJK reviewed the literature and wrote the manuscript. All authors read, edited, and approved the final manuscript.

Ethics approval and consent to participate

Not applicable.

\section{Consent for publication}

Not applicable.

\section{Competing interests}

The authors declare that they have no competing interests.

\section{Publisher's Note}

Springer Nature remains neutral with regard to jurisdictional claims in published maps and institutional affiliations.

\section{Author details \\ ${ }^{1}$ Brain Plasticity Group, SILS-CNS, University of Amsterdam, Science Park 904, 1098 XH Amsterdam, The Netherlands. ${ }^{2}$ Department of Clinical Epidemiology, Biostatistics \& Bio informatics, Academic Medical Centre, University of Amsterdam, Meibergdreef 9, 1105 AZ Amsterdam, the Netherlands. ${ }^{3}$ The Netherlands Institute for Neuroscience, an Institute of the Royal Netherlands Academy of Arts and Sciences, KNAW, Meibergdreef 47, 1105 BA Amsterdam, The Netherlands. ${ }^{4}$ Department of Cellular and Computational Neuroscience, SILS-CNS, University of Amsterdam, Science Park 904, 1098 XH Amsterdam, The Netherlands.}

Received: 26 February 2018 Accepted: 15 August 2018

Published online: 19 September 2018

\section{References}

1. Selkoe DJ, Schenk D. Alzheimer's disease: molecular understanding predicts amyloid-based therapeutics. Annu Rev Pharmacol Toxicol. 2003;43:545-84 https://doi.org/10.1146/annurev.pharmtox.43.100901.140248.

2. Terry RD, Masliah E, Salmon DP, Butters N, DeTeresa R, Hill R, et al. Physical basis of cognitive alterations in Alzheimer's disease: synapse loss is the major correlate of cognitive impairment. Ann Neurol. 1991;30:572-80. https://doi.org/10.1002/ana.410300410. 
3. Querfurth HW, LaFerla FM. Alzheimer's disease. N Engl J Med. 2010;362:329-44. https://doi.org/10.1056/NEJMra0909142.

4. Scheltens P, Blennow K, Breteler MMB, de Strooper B, Frisoni GB, Salloway S, et al. Alzheimer's disease. Lancet. 2016;388:505-17.

5. Campion D, Dumanchin C, Hannequin D, Dubois B, Belliard S, Puel M, et al. Early-onset autosomal dominant Alzheimer disease: prevalence, genetic heterogeneity, and mutation spectrum. Am J Hum Genet. 1999;65:664-70.

6. Matthews FE, Arthur A, Barnes LE, Bond J, Jagger C, Robinson L, et al. A two-decade comparison of prevalence of dementia in individuals aged 65 years and older from three geographical areas of England: results of the Cognitive Function and Ageing Study I and II. Lancet. 2013;382: 1405-12.

7. Baumgart M, Snyder HM, Carrillo MC, Fazio S, Kim H, Johns H. Summary of the evidence on modifiable risk factors for cognitive decline and dementia: a population-based perspective. Alzheimers Dement. 2015;11:718-26. https://doi.org/10.1016/j.jalz.2015.05.016.

8. Xu W, Tan L, Wang H-F, Jiang T, Tan M-S, Tan L, et al. Meta-analysis of modifiable risk factors for Alzheimer's disease. Cogn Neurol. 2015;86:1299-306. https:/doi.org/10.1136/innp-2015-310548.

9. Abbott RD, White LR, Ross GW, Masaki KH, Curb JD, Petrovitch H. Walking and dementia in physically capable elderly men. JAMA. 2004;292:1447. https://doi.org/10.1001/jama.292.12.1447.

10. Barnard ND, Bush Al, Ceccarelli A, Cooper J, de Jager CA, Erickson Kl, et al. Dietary and lifestyle guidelines for the prevention of Alzheimer's disease. Neurobiol Aging. 2014;35:S74-8. https://doi.org/10.1016/J.NEUROBIOLAGING.2014.03.033.

11. Daffner KR. Promoting successful cognitive aging: a comprehensive review. J Alzheimers Dis. 2010;19:1101-22. https://doi.org/10.3233/JAD-2010-1306.

12. Fratiglioni L, Qiu C. Prevention of common neurodegenerative disorders in the elderly. Exp Gerontol. 2009:44:46-50.

13. Friedland RP, Fritsch T, Smyth KA, Koss E, Lerner AJ, Chen CH, et al. Patients with Alzheimer's disease have reduced activities in midlife compared with healthy control-group members. Proc Natl Acad Sci U S A. 2001;98:3440-5. https://doi.org/10.1073/pnas.061002998.

14. Gates N, Valenzuela M. Cognitive exercise and its role in cognitive function in older adults. Curr Psychiatry Rep. 2010;12:20-7. https://doi.org/10.1007/ s11920-009-0085-y.

15. Papp KV, Walsh SJ, Snyder PJ. Immediate and delayed effects of cognitive interventions in healthy elderly: a review of current literature and future directions. Alzheimers Dement. 2009;5:50-60. https://doi.org/10.1016/j.jalz.2008.10.008.

16. Riley KP, Snowdon DA, Desrosiers MF, Markesbery WR. Early life linguistic ability, late life cognitive function, and neuropathology: findings from the Nun Study. Neurobiol Aging. 2005;26:341-7. https://doi.org/10.1016/j. neurobiolaging.2004.06.019.

17. Stern Y. Cognitive reserve. Neuropsychologia. 2009;47:2015-28. https://doi. org/10.1016/j.neuropsychologia.2009.03.004.

18. Tyas SL, Snowdon DA, Desrosiers MF, Riley KP, Markesbery WR. Healthy ageing in the Nun Study: definition and neuropathologic correlates. Age Ageing. 2007;36:650-5. https://doi.org/10.1093/ageing/afm120.

19. Mejía S, Giraldo M, Pineda D, Ardila A, Lopera F. Nongenetic factors as modifiers of the age of onset of familial Alzheimer's disease. Int Psychogeriatr. 2003;15:337-49. https://doi.org/10.1017/S1041610203009591.

20. Arsenault-Lapierre G, Chertkow H, Lupien S. Seasonal effects on cortisol secretion in normal aging, mild cognitive impairment and Alzheimer's disease. Neurobiol Aging. 2010;31:1051-4.

21. Herbert J, Lucassen P. Depression as a risk factor for Alzheimer's disease: genes, steroids, cytokines and neurogenesis - what do we need to know? Neuroendocrinology. 2016:41:153-71.

22. Csernansky JG, Dong H, Fagan AM, Wang L, Xiong C, Holtzman DM, et al. Plasma cortisol and progression of dementia in subjects with Alzheimertype dementia. Am J Psychiatry. 2006;163:2164-9. https://doi.org/10.1176/ appi.ajp.163.12.2164.

23. Hoogendijk WJG, Meynen G, Endert E, Hofman MA, Swaab DF. Increased cerebrospinal fluid cortisol level in Alzheimer's disease is not related to depression. Neurobiol Aging. 2006;27:780.e1-2.

24. Rasmuson S, Näsman B, Carlström K, Olsson T. Increased levels of adrenocortical and gonadal hormones in mild to moderate Alzheimer's disease. Dement Geriatr Cogn Disord. 2002;13:74-9. http://www.scopus. com/inward/record.url?eid=2-s2.0-0036177775\&partnerlD=40\&md5= b1702d2ed86d643dd7f8df8e2c0f9491

25. Näsman B, Olsson T, Viitanen M, Carlström K. A subtle disturbance in the feedback regulation hypothalamic-pituitary-adrenal axis in the early phase of Alzheimer's disease. Psychoneuroendocrinology. 1995;20: 211-20.

26. Elgh E, Lindqvist Astot $A$, Fagerlund $M$, Eriksson S, Olsson T, Näsman B. Cognitive dysfunction, hippocampal atrophy and glucocorticoid feedback in Alzheimer's disease. Biol Psychiatry. 2006;59:155-61. https://doi.org/10.1016/ j.biopsych.2005.06.017.

27. Raadsheer FC, Van Heerikhuize JJ, Lucassen PJ, Hoogendijk WJG, Tilders FJH, Swaab DF. Corticotropin-releasing hormone mRNA levels in the paraventricular nucleus of patients with Alzheimer's disease and depression. Am J Psychiatry. 1995;152:1372-6.

28. Wang H-X, MacDonald SWS, Dekhtyar S, Fratiglioni L, Mante M, Saitoh T. Association of lifelong exposure to cognitive reserve-enhancing factors with dementia risk: a community-based cohort study. PLoS Med. 2017;14: e1002251. https://doi.org/10.1371/journal.pmed.1002251.

29. Andersen SL, Teicher MH. Stress, sensitive periods and maturational events in adolescent depression. Trends Neurosci. 2008;31:183-91. https://doi.org/ 10.1016/J.TINS.2008.01.004.

30. Cirulli F, Berry A, Alleva E. Early disruption of the mother-infant relationship: effects on brain plasticity and implications for psychopathology. Neurosci Biobehav Rev. 2003;27:73-82. https://doi.org/10.1016/S0149-7634(03)00010-1.

31. Davidson RJ, McEwen BS. Social influences on neuroplasticity: stress and interventions to promote well-being. Nat Neurosci. 2012;15:689-95. https://doi.org/10.1038/nn.3093.

32. Fox SE, Levitt P, Nelson CA III. How the timing and quality of early experiences influence the development of brain architecture. Child Dev. 2010;81:28-40. https://doi.org/10.1111/j.1467-8624.2009.01380.x.

33. Knudsen El. Sensitive periods in the development of the brain and behavior. J Cogn Neurosci. 2004;16:1412-25. https://doi.org/10.1162/ 0898929042304796.

34. Liu D, Diorio J, Day JC, Francis DD, Meaney MJ. Maternal care, hippocampal synaptogenesis and cognitive development in rats. Nat Neurosci. 2000;3: 799-806. https://doi.org/10.1038/77702.

35. Roth TL, Sweatt JD. Annual Research Review: Epigenetic mechanisms and environmental shaping of the brain during sensitive periods of development. J Child Psychol Psychiatry. 2011;52:398-408. https://doi. org/10.1111/j.1469-7610.2010.02282.x.

36. Teicher MH, Samson JA, Anderson CM, Ohashi K. The effects of childhood maltreatment on brain structure, function and connectivity. Nat Rev Neurosci. 2016;17:652-66. https://doi.org/10.1038/nrn.2016.111.

37. Bale TL, Baram TZ, Brown AS, Goldstein JM, Insel TR, McCarthy MM, et al. Early life programming and neurodevelopmental disorders. Biol Psychiatry. 2010;68:314-9. https://doi.org/10.1016/j.biopsych.2010.05.028.

38. Heim C, Binder EB. Current research trends in early life stress and depression: review of human studies on sensitive periods, geneenvironment interactions, and epigenetics. Exp Neurol. 2012;233:102-11. https://doi.org/10.1016/J.EXPNEUROL.2011.10.032.

39. McEwen BS. Central effects of stress hormones in health and disease: understanding the protective and damaging effects of stress and stress mediators. Eur J Pharmacol. 2008;583:174-85. https://doi.org/10.1016/j. ejphar.2007.11.071.

40. Raineki C, Szawka RE, Gomes CM, Lucion MK, Barp J, Belló-Klein A, et al. Effects of neonatal handling on central noradrenergic and nitric oxidergic systems and reproductive parameters in female rats. Neuroendocrinology. 2008;87:151-9. https://doi.org/10.1159/000112230.

41. Lesuis SL, van Hoek BACE, Lucassen PJ, Krugers HJ. Early postnatal handling reduces hippocampal amyloid plaque formation and enhances cognitive performance in APPswe/PS1dE9 mice at middle age. Neurobiol Learn Mem. 2017;144:27-35. https://doi.org/10.1016/J.NLM.2017.05.016.

42. Sierksma ASR, Prickaerts J, Chouliaras L, Rostamian S, Delbroek L, Rutten BPF, et al. Behavioral and neurobiological effects of prenatal stress exposure in male and female APPswe/PS1dE9 mice. Neurobiol Aging. 2013;34:319-37. https://doi.org/10.1016/j.neurobiolaging.2012.05.012.

43. Hui J, Feng $G$, Zheng $C$, Jin $H$, Jia N. Maternal separation exacerbates Alzheimer's disease-like behavioral and pathological changes in adult APPswe/PS1dE9 mice. Behav Brain Res. 2017;318:18-23. https://doi.org/10. 1016/j.bbr.2016.10.030.

44. Lesuis SL, Weggen S, Baches S, Lucassen PJ, Krugers HJ. Early life stress accelerates amyloid pathology and cognitive decline in APPswe/PS1dE9 mice; rescue by briefly blocking GRs at middle age. Transl Psychiatry. 2018;8(1):53.

45. Hoeijmakers L, Ruigrok SR, Amelianchik A, Ivan D, van Dam A-M, Lucassen $\mathrm{PJ}$, et al. Early-life stress lastingly alters the neuroinflammatory response to 
amyloid pathology in an Alzheimer's disease mouse model. Brain Behav Immun. 2016:63:160-75.

46. Lesuis SL, Maurin H, Borghgraef P, Lucassen PJ, Van Leuven F, Krugers HJ. Positive and negative early life experiences differentially modulate long term survival and amyloid protein levels in a mouse model of Alzheimer's disease. Oncotarget. 2016;7(26):39118-35.

47. Martisova E, Aisa B, Guerenu G, Ramirez M. Effects of early maternal separation on biobehavioral and neuropathological markers of Alzheimer's disease in adult male rats. Curr Alzheimer Res. 2013;10:420-32.

48. Cordner ZA, Tamashiro KLK. Effects of chronic variable stress on cognition and Bace1 expression among wild-type mice. Transl Psychiatry. 2016;6:e854. https://doi.org/10.1038/tp.2016.127.

49. Fujio J, Hosono H, Ishiguro K, Ikegami S, Fujita SC. Tau phosphorylation in the mouse brain during aversive conditioning. Neurochem Int. 2007;51:2008. https://doi.org/10.1016/j.neuint.2007.04.024.

50. Sotiropoulos I, Catania C, Pinto LG, Silva R, Pollerberg GE, Takashima A, et al. Stress acts cumulatively to precipitate Alzheimer's disease-like tau pathology and cognitive deficits. J Neurosci. 2011;31:7840-7. https://doi.org/10.1523/ JNEUROSCI.0730-11.2011

51. Yang C, Guo X, Wang GH, Wang HL, Liu ZC, Liu H, et al. Changes in tau phosphorylation levels in the hippocampus and frontal cortex following chronic stress. Brazilian J Med Biol Res $=$ Rev Bras Pesqui medicas e Biol. 2014;47:237-44. https://doi.org/10.1590/1414-431X20133275.

52. Nogueira ML, Hamraz M, Abolhassani M, Bigan E, Lafitte O, Steyaert J-M, et al. Mechanical stress increases brain amyloid $\beta$, tau, and a-synuclein concentrations in wild-type mice. Alzheimers Dement. 2017;14(4):444-53. https://doi.org/10.1016/j.jalz.2017.11.003.

53. Lopes S, Vaz-Silva J, Pinto V, Dalla C, Kokras N, Bedenk B, et al. Tau protein is essential for stress-induced brain pathology. Proc Natl Acad Sci U S A. 2016; 113:E3755-63. https://doi.org/10.1073/pnas.1600953113.

54. Cañete T, Blázquez G, Tobeña A, Giménez-Llort L, Fernández-Teruel A. Cognitive and emotional alterations in young Alzheimer's disease (3xTgAD) mice: effects of neonatal handling stimulation and sexual dimorphism. Behav Brain Res. 2015;281:156-71. https://doi.org/10.1016/j.bbr.2014.11.004.

55. Wang Y-J, Zhou H-D, Zhou X-F. Clearance of amyloid-beta in Alzheimer's disease: progress, problems and perspectives. Drug Discov Today. 2006;11: 931-8. https://doi.org/10.1016/J.DRUDIS.2006.08.004.

56. de Kloet $E_{1}$ Joëls $M$, Holsboer F. Stress and the brain: from adaptation to disease. Nat Rev Neurosci. 2005;6:463-75. https://doi.org/10.1038/nrn1683.

57. Davis KL, Davis BM, Greenwald BS, Mohs RC, Mathé AA, Johns CA, et al. Cortisol and Alzheimer's disease. I: basal studies. Am J Psychiatry. 1986;143:300-5.

58. Masugi F, Ogihara T, Sakaguchi K, Otsuka A, Tsuchiya Y, Morimoto S, et al. High plasma levels of cortisol in patients with senile dementia of the Alzheimer's type. Methods Find Exp Clin Pharmacol. 1989;11:707-10. http://www.ncbi.nlm.nih.gov/pubmed/2560104. Accessed 21 Feb 2016

59. Olsson T, Näsman B, Rasmuson S, Ahrén B. Dual relation between leptin and cortisol in humans is disturbed in Alzheimer's disease. Biol Psychiatry. 1998;44:374-6. http://www.ncbi.nlm.nih.gov/pubmed/9755363. Accessed 22 Apr 2017

60. Näsman B, Olsson T, Fagerlund M, Eriksson S, Viitanen M, Carlström K. Blunted adrenocorticotropin and increased adrenal steroid response to human corticotropin-releasing hormone in Alzheimer's disease. Biol Psychiatry. 1996;39:311-8.

61. Greenwald BS, Mathé AA, Mohs RC, Levy M, Johns CA, Davis KL. Cortisol and Alzheimer's disease, II: dexamethasone suppression, dementia severity, and affective symptoms. Am J Psychiatry. 1986;143:442-6.

62. Popp J, Wolfsgruber S, Heuser I, Peters O, Hüll M, Schröder J, et al. Cerebrospinal fluid cortisol and clinical disease progression in $\mathrm{MCl}$ and dementia of Alzheimer's type. Neurobiol Aging. 2015;36:601-7. https://doi. org/10.1016/j.neurobiolaging.2014.10.031.

63. Swanwick GRJ, Kirby M, Bruce I, Buggy F, Coen RF, Coakley D, et al. Hypothalamicpituitary-adrenal axis dysfunction in Alzheimer's disease: lack of association between longitudinal and cross-sectional findings. Am J Psychiatry. 1998;155:286-9.

64. Swaab DF, Bao A-M, Lucassen PJ. The stress system in the human brain in depression and neurodegeneration. Ageing Res Rev. 2005;4:141-94.

65. Green K, Billings L, Roozendaal B, McGaugh J, LaFerla F. Glucocorticoids increase amyloid- $\beta$ and tau pathology in a mouse model of Alzheimer's disease. J Neurosci. 2006;26:9047-56. https://doi.org/10.1523/JNEUROSCl.2797-06.2006.

66. Catania C, Sotiropoulos I, Silva R, Onofri C, Breen KC, Sousa N, et al. The amyloidogenic potential and behavioral correlates of stress. Mol Psychiatry. 2009;14:95-105.
67. Vallée M, Mayo W, Dellu F, Le Moal M, Simon H, Maccari S. Prenatal stress induces high anxiety and postnatal handling induces low anxiety in adult offspring: correlation with stress-induced corticosterone secretion. J Neurosci. 1997;17:2626-36. http://www.ncbi.nlm.nih.gov/pubmed/9065522. Accessed 9 Dec 2017

68. Ivy AS, Rex CS, Chen Y, Maras PM, Grigoriadis DE, Gall CM, et al. Hippocampal dysfunction and cognitive impairments provoked by chronic early-life stress involve excessive activation of CRH receptors. J Neurosci. 2010;30:13005-15.

69. Lucassen PJ, Mü MB, Holsboer F, Bauer J, Holtrop A, Wouda J, et al. Hippocampal apoptosis in major depression is a minor event and absent from subareas at risk for glucocorticoid overexposure. Am J Pathol. 2001; 158:453-68. https://doi.org/10.1016/S0002-9440(10)63988-0.

70. Müller MB, Lucassen PJ, Yassouridis A, Hoogendijk WJ, Holsboer F, Swaab DF. Neither major depression nor glucocorticoid treatment affects the cellular integrity of the human hippocampus. Eur J Neurosci. 2001;14:1603-12. http:// www.ncbi.nlm.nih.gov/pubmed/11860455. Accessed 5 Feb 2018

71. Solas M, Aisa B, Tordera RM, Mugueta MC, Ramírez MJ. Stress contributes to the development of central insulin resistance during aging: implications for Alzheimer's disease. Biochim Biophys Acta. 1832;2013:2332-9. https://doi. org/10.1016/j.bbadis.2013.09.013.

72. Solas M, Aisa B, Mugueta MC, Del Río J, Tordera RM, Ramírez MJ. Interactions between age, stress and insulin on cognition: implications for Alzheimer's disease. Neuropsychopharmacology. 2010;35:1664-73. https:// doi.org/10.1038/npp.2010.13

73. Sambamurti K, Kinsey R, Maloney B, Ge Y, Lahiri D. Gene structure and organization of the human $\beta$-secretase (BACE) promoter. FASEB J. 2004;18: 1034-6. https://doi.org/10.1096/fj.03-1378fje.

74. Baglietto-Vargas D, Medeiros R, Martinez-Coria H, Laferla FM, Green KN. Mifepristone alters amyloid precursor protein processing to preclude amyloid beta and also reduces tau pathology. Biol Psychiatry. 2013;74:35766. https://doi.org/10.1016/j.biopsych.2012.12.003.

75. Martisova E, Solas M, Gerenu G, Milagro Fl, Campion J, Ramirez MJ. Mechanisms involved in BACE upregulation associated to stress. Curr Alzheimer Res. 2012;9:822-9. http://www.ncbi.nlm.nih.gov/pubmed/ 22631614. Accessed 14 Dec 2017

76. De Souza EB, Whitehouse PJ, Price DL, Vale WW. Abnormalities in corticotropin-releasing hormone $(\mathrm{CRH})$ in Alzheimer's disease and other human disorders. Ann N Y Acad Sci. 1987;512:237-47. http://www.ncbi.nlm. nih.gov/pubmed/3502064. Accessed 30 Dec 2017

77. May C, Rapoport SI, Tomai TP, Chrousos GP, Gold PW. Cerebrospinal fluid concentrations of corticotropin-releasing hormone $(\mathrm{CRH})$ and corticotropin $(\mathrm{ACTH})$ are reduced in patients with Alzheimer's disease. Neurology. 1987;37: 535-8. http://www.ncbi.nlm.nih.gov/pubmed/3029628. Accessed 30 Dec 2017

78. Pedersen WA, McCullers D, Culmsee C, Haughey NJ, Herman JP, Mattson MP. Corticotropin-releasing hormone protects neurons against insults relevant to the pathogenesis of Alzheimer's disease. Neurobiol Dis. 2001;8: 492-503. https://doi.org/10.1006/nbdi.2001.0395.

79. Lezoualc'h F, Engert S, Berning B, Behl C. Corticotropin-releasing hormonemediated neuroprotection against oxidative stress is associated with the increased release of non-amyloidogenic amyloid beta precursor protein and with the suppression of nuclear factor-kappaB. Mol Endocrinol. 2000;14:147-59. https://doi.org/10.1210/mend.14.1.0403.

80. Bayatti $\mathrm{N}$, Behl $\mathrm{C}$. The neuroprotective actions of corticotropin releasing hormone. Ageing Res Rev. 2005;4:258-70. https:/doi.org/10.1016/j.arr.2005.02.004

81. Baglietto-Vargas D, Chen Y, Suh D, Ager RR, Rodriguez-Ortiz CJ, Medeiros R, et al. Short-term modern life-like stress exacerbates $A \beta$-pathology and synapse loss in 3xTg-AD mice. J Neurochem. 2015;134:915-26. https:/doi.org/10.1111/jnc.13195.

82. Dong H, Murphy KM, Meng L, Montalvo-Ortiz J, Zeng Z, Kolber BJ, et al. Corticotrophin releasing factor accelerates neuropathology and cognitive decline in a mouse model of Alzheimer's disease. J Alzheimers Dis. 2012;28: 579-92. https://doi.org/10.3233/JAD-2011-111328.

83. Aisa B, Gil-Bea FJ, Marcos B, Tordera R, Lasheras B, Del Río J, et al. Neonatal stress affects vulnerability of cholinergic neurons and cognition in the rat: involvement of the HPA axis. Psychoneuroendocrinology. 2009;34:1495-505. https://doi.org/10.1016/j.psyneuen.2009.05.003.

84. Hebda-Bauer EK, Simmons TA, Sugg A, Ural E, Stewart JA, Beals JL, et al. 3xTg$\mathrm{AD}$ mice exhibit an activated central stress axis during early-stage pathology. J Alzheimers Dis. 2013:33:407-22. https://doi.org/10.3233/JAD-2012-121438.

85. Roberts KF, Elbert DL, Kasten TP, Patterson BW, Sigurdson WC, Connors RE, et al. Amyloid- $\beta$ efflux from the central nervous system into the plasma. Ann Neurol. 2014;76:837-44. https://doi.org/10.1002/ana.24270. 
86. Kanekiyo T, Cirrito JR, Liu C-C, Shinohara M, Li J, Schuler DR, et al. Neurona clearance of Amyloid- $\beta$ by endocytic receptor LRP1. J Neurosci. 2013;33: 19276-83. https://doi.org/10.1523/JNEUROSCI.3487-13.2013.

87. Deane R, Du Yan S, Submamaryan RK, LaRue B, Jovanovic S, Hogg E, et al. RAGE mediates amyloid- $\beta$ peptide transport across the blood-brain barrier and accumulation in brain. Nat Med. 2003;9:907-13. https://doi.org/10. 1038/nm890.

88. Montagne A, Barnes SR, Sweeney MD, Halliday MR, Sagare AP, Zhao Z, et al. Blood-brain barrier breakdown in the aging human hippocampus. Neuron. 2015;85:296-302. https://doi.org/10.1016/j.neuron.2014.12.032.

89. Menard C, Pfau ML, Hodes GE, Kana V, Wang VX, Bouchard S, et al. Social stress induces neurovascular pathology promoting depression. Nat Neurosci. 2017;20:1752-60. https://doi.org/10.1038/s41593-017-0010-3.

90. Sántha P, Veszelka S, Hoyk Z, Mészáros M, Walter FR, Tóth AE, et al. Restraint stress-induced morphological changes at the blood-brain barrier in adult rats. Front Mol Neurosci. 2016;8:88. https://doi.org/10.3389/fnmol.2015.00088.

91. Lee CYD, Landreth GE. The role of microglia in amyloid clearance from the AD brain. J Neural Transm. 2010;117:949-60. https://doi.org/10.1007/s00702010-0433-4.

92. Farris W, Mansourian S, Chang Y, Lindsley L, Eckman EA, Frosch MP, et al. Insulin-degrading enzyme regulates the levels of insulin, amyloid betaprotein, and the beta-amyloid precursor protein intracellular domain in vivo. Proc Natl Acad Sci U S A. 2003;100:4162-7. https://doi.org/10.1073/pnas. 0230450100

93. Harada S, Smith R, Hu D, Jarett L. Dexamethasone inhibits insulin binding to insulin-degrading enzyme and cytosolic insulin-binding protein p82. Biochem Biophys Res Commun. 1996;218:154-8.

94. Osborn LM, Kamphuis W, Wadman WJ, Hol EM. Astrogliosis: an integral player in the pathogenesis of Alzheimer's disease. Prog Neurobiol. 2016;144:121-41.

95. ElAli A, Rivest S. Microglia in Alzheimer's disease: a multifaceted relationship. Brain Behav Immun. 2016;55:138-50. https://doi.org/10.1016/j.bbi.2015.07.021.

96. Pekny M, Pekna M, Messing A, Steinhäuser C, Lee J-M, Parpura V, et al. Astrocytes: a central element in neurological diseases. Acta Neuropathol. 2016;131:323-45. https://doi.org/10.1007/s00401-015-1513-1.

97. Heneka MT, Carson MJ, El Khoury J, Landreth GE, Brosseron F, Feinstein DL, et al. Neuroinflammation in Alzheimer's disease. Lancet Neurol. 2015;14:388405. https://doi.org/10.1016/S1474-4422(15)70016-5.

98. Hoeijmakers L, Lucassen PJ, Korosi A. The interplay of early-life stress, nutrition, and immune activation programs adult hippocampal structure and function. Front Mol Neurosci. 2015;7:103. https://doi.org/10.3389/fnmol. 2014.00103.

99. Hoeijmakers L, Heinen Y, van Dam A-M, Lucassen PJ, Korosi A. Microglial priming and Alzheimer's disease: a possible role for (early) immune challenges and epigenetics? Front Hum Neurosci. 2016;10:398. https://doi. org/10.3389/fnhum.2016.00398.

100. Johnson FK, Kaffman A. Early life stress perturbs the function of microglia in the developing rodent brain: new insights and future challenges. Brain Behav Immun. 2017;69:18-27. https://doi.org/10.1016/j.bbi.2017.06.008.

101. Li Q, Barres BA. Microglia and macrophages in brain homeostasis and disease. Nat Rev Immunol. 2018;18(4):225-42. https://doi.org/10.1038/nri. 2017.125.

102. Füger $P$, Hefendehl JK, Veeraraghavalu $K$, Wendeln A-C, Schlosser $C$, Obermüller $U$, et al. Microglia turnover with aging and in an Alzheimer's model via long-term in vivo single-cell imaging. Nat Neurosci. 2017;20: 1371-6. https://doi.org/10.1038/nn.4631.

103. Liddelow SA, Guttenplan KA, Clarke LE, Bennett FC, Bohlen CJ, Schirmer L, et al. Neurotoxic reactive astrocytes are induced by activated microglia. Nature. 2017;541:481-7. https://doi.org/10.1038/nature21029.

104. Hong S, Beja-Glasser VF, Nfonoyim BM, Frouin A, Li S, Ramakrishnan S, et al. Complement and microglia mediate early synapse loss in Alzheimer mouse models. Science. 2016;352:712-6. https://doi.org/10.1126/science.aad8373.

105. Schwarz JM, Hutchinson MR, Bilbo SD. Early-life experience decreases druginduced reinstatement of morphine CPP in adulthood via microglial-specific epigenetic programming of anti-inflammatory IL-10 expression. J Neurosci. 2011;31:17835-47. https://doi.org/10.1523/JNEUROSCI.3297-11.2011.

106. Swaab DF. Brain aging and Alzheimer's disease, "wear and tear" versus "use it or lose it". Neurobiol Aging. 12:317-24. http://www.ncbi.nlm.nih.gov/ pubmed/1755879. Accessed 11 Feb 2018

107. Ince G. Pathological correlates of late-onset dementia in a multicentre, community-based population in England and Wales. Lancet. 2001;357:16975. https://doi.org/10.1016/S0140-6736(00)03589-3.
108. Stern Y, Gurland B, Tatemichi TK, Tang MX, Wilder D, Mayeux R. Influence of education and occupation on the incidence of Alzheimer's disease. JAMA J Am Med Assoc. 1994;271:1004. https://doi.org/10.1001/jama.1994. 03510370056032.

109. Bennett DA, Wilson RS, Schneider JA, Evans DA, Mendes de Leon CF, Arnold SE, et al. Education modifies the relation of AD pathology to level of cognitive function in older persons. Neurology. 2003;60:1909-15. http://www.ncbi.nlm.nih.gov/pubmed/12821732. Accessed 18 Apr 2017

110. Dekhtyar S, Wang H-X, Scott K, Goodman A, Koupil I, Herlitz A. A life-course study of cognitive reserve in dementia-from childhood to old age. Am J Geriatr Psychiatry. 2015;23:885-96. https://doi.org/10.1016/j.jagp.2015.02.002.

111. Scarmeas N, Levy G, Tang MX, Manly J, Stern Y. Influence of leisure activity on the incidence of Alzheimer's disease. Neurology. 2001;57:2236-42. http://www.ncbi.nlm.nih.gov/pubmed/11756603. Accessed 20 Dec 2017

112. Bartolotti N, Lazarov O. Lifestyle and Alzheimer's disease. In: Genes, environment and Alzheimer's disease. London: Elsevier; 2016. p. 197-237. https://doi.org/10.1016/B978-0-12-802851-3.00007-3.

113. Ravona-Springer R, Beeri MS, Goldbourt U. Younger age at crisis following parental death in male children and adolescents is associated with higher risk for dementia at old age. Alzheimer Dis Assoc Disord. 2012;26:68-73. https://doi.org/10.1097/WAD.0b013e3182191f86.

114. Bloss EB, Janssen WG, Ohm DT, Yuk FJ, Wadsworth S, Saardi KM, et al. Evidence for reduced experience-dependent dendritic spine plasticity in the aging prefrontal cortex. J Neurosci. 2011;31:7831-9. https://doi.org/10.1523/ JNEUROSCI.0839-11.2011.

115. Wagner AP, Schmoll H, Badan I, Platt D, Kessler C. Brain plasticity: to what extent do aged animals retain the capacity to coordinate gene activity in response to acute challenges. Exp Gerontol. 2000;35:1211-27. http://ac.elscdn.com/S0531556500001546/1-s2.0-S0531556500001546-main.pdf?_tid= cf065e9a-2447-11e7-8237-00000aacb35e\&acdnat=1492527829 6ae9053199753dcba936a1a713cb3b78. Accessed 18 Apr 2017

116. Stern Y, Albert S, Tang MX, Tsai WY. Rate of memory decline in AD is related to education and occupation: cognitive reserve? Neurology. 1999;53: 1942-7. https://doi.org/10.1212/WNL.53.9.1942.

117. Scarmeas N, Albert SM, Manly JJ, Stern Y. Education and rates of cognitive decline in incident Alzheimer's disease. J Neurol Neurosurg Psychiatry. 2006; 77:308-16. https://doi.org/10.1136/jnnp.2005.072306.

118. Barulli D, Stern Y. Efficiency, capacity, compensation, maintenance, plasticity: emerging concepts in cognitive reserve. Trends Cogn Sci. 2013;17:502-9. https://doi.org/10.1016/j.tics.2013.08.012

119. Granger MW, Franko B, Taylor MW, Messier C, George-Hyslop PS, Bennett SAL. A TgCRND8 mouse model of Alzheimer's disease exhibits sexual dimorphisms in behavioral indices of cognitive reserve. J Alzheimers Dis. 2016;51:757-73. https://doi.org/10.3233/JAD-150587.

120. Vogel S, Klumpers F, Kroes MCW, Oplaat KT, Krugers HJ, Oitzl MS, et al. A stress-induced shift from trace to delay conditioning depends on the mineralocorticoid receptor. Biol Psychiatry. 2015;78:830-9. https://doi.org/10. 1016/j.biopsych.2015.02.014.

121. Schwabe L, Dalm S, Schächinger H, Oitzl MS. Chronic stress modulates the use of spatial and stimulus-response learning strategies in mice and man. Neurobiol Learn Mem. 2008;90:495-503. https://doi.org/10.1016/j.n/m.2008.07.015.

122. Schwabe L, Tegenthoff M, Höffken O, Wolf OT. Mineralocorticoid receptor blockade prevents stress-induced modulation of multiple memory systems in the human brain. Biol Psychiatry. 2013;74:801-8. https://doi.org/10.1016/j. biopsych.2013.06.001.

123. Schwabe $L$, Wolf OT. Stress and multiple memory systems: from "thinking" to "doing". Trends Cogn Sci. 2013;17:60-8. https://doi.org/10.1016/j.tics.2012.12.001.

124. Schwabe $L$, Schächinger $H$, de Kloet ER, Oitzl MS. Stress impairs spatial but not early stimulus-response learning. Behav Brain Res. 2010;213:50-5. https://doi.org/10.1016/j.bbr.2010.04.029.

125. Schwabe L, Schächinger $H$, de Kloet ER, Oitzl MS. Corticosteroids operate as a switch between memory systems. J Cogn Neurosci. 2010;22:1362-72. https://doi.org/10.1162/jocn.2009.21278.

126. Sutherland RJ, McDonald RJ, Savage DD. Prenatal exposure to moderate levels of ethanol can have long-lasting effects on hippocampal synaptic plasticity in adult offspring. Hippocampus. 1997;7:232-8. https://doi.org/10. 1002/(SICI)1098-1063(1997)7:2<232::AID-HIPO9>3.0.CO;2-O.

127. Schwabe $L$, Bohbot VD, Wolf OT. Prenatal stress changes learning strategies in adulthood. Hippocampus. 2012;22:2136-43. https://doi.org/10.1002/hipo.22034.

128. Grissom EM, Hawley WR, Bromley-Dulfano SS, Marino SE, Stathopoulos NG, Dohanich GP. Learning strategy is influenced by trait anxiety and early rearing 
conditions in prepubertal male, but not prepubertal female rats. Neurobiol Learn Mem. 2012;98:174-81. https://doi.org/10.1016/j.nlm.2012.06.001.

129. Bock J, Gruss M, Becker S, Braun K. Experience-induced changes of dendritic spine densities in the prefrontal and sensory cortex: correlation with developmental time windows. Cereb Cortex. 2005;15:802-8. https:// doi.org/10.1093/cercor/bhh181.

130. Bock J, Murmu MS, Biala Y, Weinstock M, Braun K. Prenatal stress and neonatal handling induce sex-specific changes in dendritic complexity and dendritic spine density in hippocampal subregions of prepubertal rats. Neuroscience. 2011;193:3443. https://doi.org/10.1016/j.neuroscience.2011.07.048.

131. Murmu MS, Salomon S, Biala Y, Weinstock M, Braun K, Bock J. Changes of spine density and dendritic complexity in the prefrontal cortex in offspring of mothers exposed to stress during pregnancy. Eur J Neurosci. 2006;24: 1477-87. https://doi.org/10.1111/j.1460-9568.2006.05024.x.

132. Kolb B, Mychasiuk R, Muhammad A, Li Y, Frost DO, Gibb R. Experience and the developing prefrontal cortex. Proc Natl Acad Sci U S A. 2012;109(Suppl 2):17186-93. https://doi.org/10.1073/pnas.1121251109.

133. McEwen BS, Eiland L, Hunter RG, Miller MM. Stress and anxiety: structural plasticity and epigenetic regulation as a consequence of stress. Neuropharmacology. 2012; 62:3-12. https://doi.org/10.1016/j.neuropharm.2011.07.014.

134. Brunson KL, Kramár E, Lin B, Chen Y, Colgin LL, Yanagihara TK, et al. Mechanisms of late-onset cognitive decline after early-life stress. J Neurosci. 2005;25:9328-38. https://doi.org/10.1523/JNEUROSCI.2281-05.2005.

135. Wang X-D, Rammes G, Kraev I, Wolf M, Liebl C, Scharf SH, et al. Forebrain $\mathrm{CRF}_{1}$ modulates early-life stress-programmed cognitive deficits. J Neurosci. 2011;31:13625-34. https://doi.org/10.1523/JNEUROSCI.2259-11.2011.

136. Yang X, Liao X, Uribe-Mariño A, Liu R, Xie X, Jia J, et al. Stress during a critical postnatal period induces region-specific structural abnormalities and dysfunction of the prefrontal cortex via CRF1. Neuropsychopharmacology. 2015;40(5):1203-15. https://doi.org/10.1038/npp.2014.304.

137. Guadagno A, Wong TP, Walker C-D. Morphological and functional changes in the preweaning basolateral amygdala induced by early chronic stress associate with anxiety and fear behavior in adult male, but not female rats. Prog Neuro-Psychopharmacology Biol Psychiatry. 2018;81:25-37. https://doi. org/10.1016/j.pnpbp.2017.09.025.

138. Bagot $R$, van Hasselt F, Champagne D, Meaney M, Krugers $H$, Joëls M. Maternal care determines rapid effects of stress mediators on synaptic plasticity in adult rat hippocampal dentate gyrus. Neurobiol Learn Mem. 2009;92:292-300. https://doi.org/10.1016/j.nlm.2009.03.004.

139. Champagne D, Bagot R, van Hasselt F, Ramakers G, Meaney M, de Kloet E, et al. Maternal care and hippocampal plasticity: evidence for experiencedependent structural plasticity, altered synaptic functioning, and differential responsiveness to glucocorticoids and stress. J Neurosci. 2008;28:6037-45. https://doi.org/10.1523/JNEUROSCI.0526-08.2008.

140. Chocyk A, Bobula B, Dudys D, Przyborowska A, Majcher-Maślanka I, Hess G, et al. Early-life stress affects the structural and functional plasticity of the medial prefrontal cortex in adolescent rats. Eur J Neurosci. 2013:38:2089_ 107. https://doi.org/10.1111/ejn.12208.

141. Oomen CA, Soeters H, Audureau N, Vermunt L, Van Hasselt FN, Manders EMM, et al. Early maternal deprivation affects dentate gyrus structure and emotional learning in adult female rats. Psychopharmacology. 2011;214:249-60.

142. Oomen CA, Soeters H, Audureau N, Vermunt L, van Hasselt FN, Manders $E M M$, et al. Severe early life stress hampers spatial learning and neurogenesis, but improves hippocampal synaptic plasticity and emotional learning under high-stress conditions in adulthood. J Neurosci. 2010;30: 6635-45. https://doi.org/10.1523/JNEUROSCI.0247-10.2010.

143. Krugers HJ, Oomen CA, Gumbs M, Li M, Velzing EH, Joels M, et al. Maternal deprivation and dendritic complexity in the basolateral amygdala. Neuropharmacology. 2012;62:534-7. https://doi.org/10.1016/j.neuropharm. 2011.09.022.

144. Harris JA, Devidze N, Verret L, Ho K, Halabisky B, Thwin MT, et al, Transsynaptic progression of amyloid- $\beta$-induced neuronal dysfunction within the entorhinal-hippocampal network. Neuron. 2010;68:428-41. https://doi.org/10.1016/j.neuron.2010.10.020.

145. Reinders NR, Pao Y, Renner MC, da Silva-Matos CM, Lodder TR, Malinow R, et al. Amyloid- $\beta$ effects on synapses and memory require AMPA receptor subunit GluA3. Proc Natl Acad Sci U S A. 2016;113:6526-34. https://doi.org/ 10.1073/pnas.1614249113.

146. Nimmrich V, Ebert U. Is Alzheimer's disease a result of presynaptic failure? Synaptic dysfunctions induced by oligomeric $\beta$-amyloid. Rev Neurosci. 2009; 20:1-12. https://doi.org/10.1515/REVNEURO.2009.20.1.1.
147. Lambert MP, Barlow AK, Chromy BA, Edwards C, Freed R, Liosatos M, et al Diffusible, nonfibrillar ligands derived from $A \beta 1-42$ are potent central nervous system neurotoxins. Neurobiology. 1998;95:6448-53. http://www. pnas.org/content/95/11/6448.full.pdf. Accessed 1 Jan 2018

148. Wang H-W, Pasternak JF, Kuo H, Ristic H, Lambert MP, Chromy B, et al. Soluble oligomers of $\beta$ amyloid (1-42) inhibit long-term potentiation but not long-term depression in rat dentate gyrus. Brain Res. 2002;924:133-40. https://doi.org/10.1016/S0006-8993(01)03058-X.

149. Lesné $S$, Koh MT, Kotilinek L, Kayed R, Glabe CG, Yang A, et al. A specific amyloid- $\beta$ protein assembly in the brain impairs memory. Nature. 2006;440: 352-7. https://doi.org/10.1038/nature04533.

150. Shankar GM, Bloodgood BL, Townsend M, Walsh DM, Selkoe DJ, Sabatini BL. Natural oligomers of the Alzheimer amyloid- $\beta$ protein induce reversible synapse loss by modulating an NMDA-type glutamate receptor-dependent signaling pathway. Nat Med. 2008;14:837-42. https://doi.org/10.1523/ JNEUROSCI.4970-06.2007.

151. Barry AE, Klyubin I, Mc Donald JM, Mably AJ, Farrell MA, Scott M, et al. Alzheimer's disease brain-derived amyloid- $\beta$-mediated inhibition of LTP in vivo is prevented by immunotargeting cellular prion protein. J Neurosci. 2011;31:7259-63. https://doi.org/10.1523/JNEUROSCI.6500-10.2011.

152. Kamenetz F, Tomita T, Hsieh H, Seabrook G, Borchelt D, Iwatsubo T, et al. APP processing and synaptic function. Neuron. 2003;37:925-37. https://doi. org/10.1016/S0896-6273(03)00124-7.

153. Bagot RC, Tse YC, Nguyen H-B, Wong AS, Meaney MJ, Wong TP. Maternal care influences hippocampal N-methyl-D-aspartate receptor function and dynamic regulation by corticosterone in adulthood. Biol Psychiatry. 2012;72: 491-8. https://doi.org/10.1016/J.BIOPSYCH.2012.03.016.

154. Nguyen H-B, Bagot RC, Diorio J, Wong TP, Meaney MJ. Maternal care differentially affects neuronal excitability and synaptic plasticity in the dorsal and ventral hippocampus. Neuropsychopharmacology. 2015;40:1590-9. https://doi.org/10.1038/npp.2015.19.

155. Derks NAV, Krugers HJ, Hoogenraad CC, Joëls M, Sarabdjitsingh RA. Effects of early life stress on synaptic plasticity in the developing hippocampus of male and female rats. PLoS One. 2016;11:e0164551. https://doi.org/10.1371/ journal.pone.0164551.

156. Son GH, Geum D, Chung S, Kim EJ, Jo J-H, Kim C-M, et al. Maternal stress produces learning deficits associated with impairment of NMDA receptormediated synaptic plasticity. J Neurosci. 2006;26:3309-18. https://doi.org/10. 1523/JNEUROSCI.3850-05.2006.

157. Yang J, Hou C, Ma N, Liu J, Zhang Y, Zhou J, et al. Enriched environment treatment restores impaired hippocampal synaptic plasticity and cognitive deficits induced by prenatal chronic stress. Neurobiol Learn Mem. 2007;87: 257-63. https://doi.org/10.1016/j.nlm.2006.09.001.

158. Liu X-B, Murray KD, Jones EG. Switching of NMDA receptor $2 A$ and $2 B$ subunits at thalamic and cortical synapses during early postnatal development. J Neurosci. 2004;24:8885-95. https://doi.org/10.1523/ JNEUROSCI.2476-04.2004.

159. Rodenas-Ruano A, Chávez AE, Cossio MJ, Castillo PE, Zukin RS. RESTdependent epigenetic remodeling promotes the developmental switch in synaptic NMDA receptors. Nat Neurosci. 2012;15:1382-90. https://doi.org/10. 1038/nn.3214.

160. Ballas N, Mandel G. The many faces of REST oversee epigenetic programming of neuronal genes. Curr Opin Neurobiol. 2005;15:500-6. https://doi.org/10.1016/j.conb.2005.08.015.

161. Singh-Taylor A, Molet J, Jiang S, Korosi A, Bolton JL, Noam Y, et al. NRSFdependent epigenetic mechanisms contribute to programming of stresssensitive neurons by neonatal experience, promoting resilience. Mol Psychiatry. 2017; https://doi.org/10.1038/mp.2016.240.

162. Kessels HW, Nabavi S, Malinow R. Metabotropic NMDA receptor function is required for $\beta$-amyloid-induced synaptic depression. Proc Natl Acad Sci U S A. 2013;110:4033-8. https://doi.org/10.1073/pnas.1219605110.

163. Lu T, Aron L, Zullo J, Pan Y, Kim H, Chen Y, et al. REST and stress resistance in ageing and Alzheimer's disease. Nature. 2014;507:448-54. https://doi.org/ 10.1038/nature13163.

164. Steward O, Wallace CS, Lyford GL, Worley PF. Synaptic activation causes the mRNA for the IEG Arc to localize selectively near activated postsynaptic sites on dendrites. Neuron. 1998;21:741-51. http://www.ncbi.nlm.nih.gov/ pubmed/9808461. Accessed 30 Dec 2017

165. Knapska E, Kaczmarek L. A gene for neuronal plasticity in the mammalian brain: Zif268/Egr-1/NGFI-A/Krox-24/TIS8/ZENK? Prog Neurobiol. 2004;74:183211. https://doi.org/10.1016/j.pneurobio.2004.05.007. 
166. Tzingounis AV, Nicoll RA. Arc/Arg3.1: Linking gene expression to synaptic plasticity and memory. Neuron. 2006;52:403-7. https://doi.org/10.1016/j. neuron.2006.10.016.

167. Bramham CR, Worley PF, Moore MJ, Guzowski JF. The immediate early gene Arc/Arg3.1: regulation, mechanisms, and function. J Neurosci. 2008;28: 11760-7. https://doi.org/10.1523/JNEUROSCI.3864-08.2008.

168. Korb E, Finkbeiner S. Arc in synaptic plasticity: from gene to behavior. Trends Neurosci. 2011;34:591-8. https://doi.org/10.1016/j.tins.2011.08.007.

169. Veyrac A, Besnard A, Caboche J, Davis S, Laroche S. The transcription factor Zif268/Egr1, brain plasticity, and memory. Prog Mol Biol Transl Sci. 2014. p. 89-129. https://doi.org/10.1016/B978-0-12-420170-5.00004-0.

170. Jones MW, Errington ML, French PJ, Fine A, Bliss TVP, Garel S, et al. A requirement for the immediate early gene Zif268 in the expression of late LTP and long-term memories. Nat Neurosci. 2001;4:289-96. https://doi.org/10.1038/85138.

171. Penke Z, Morice E, Veyrac A, Gros A, Chagneau C, LeBlanc P, et al. Zif268/ Egr1 gain of function facilitates hippocampal synaptic plasticity and longterm spatial recognition memory. Philos Trans R Soc Lond Ser B Biol Sci. 2014;369:20130159. https://doi.org/10.1098/rstb.2013.0159.

172. Brennan PA, Schellinck HM, Keverne EB. Patterns of expression of the immediate-early gene egr-1 in the accessory olfactory bulb of female mice exposed to pheromonal constituents of male urine. Neuroscience. 1999;90: 1463-70. https://doi.org/10.1016/S0306-4522(98)00556-9.

173. Hall J, Thomas KL, Everitt BJ. Rapid and selective induction of BDNF expression in the hippocampus during contextual learning. Nat Neurosci. 2000;3:533-5. https://doi.org/10.1038/75698.

174. Besnard A, Serge L, Jocelyne C. Comparative dynamics of MAPK/ERK signalling components and immediate early genes in the hippocampus and amygdala following contextual fear conditioning and retrieval. Brain Struct Funct. 2014;219:415-30. https://doi.org/10.1007/s00429-013-0505-y.

175. Maddox SA, Monsey MS, Schafe GE. Early growth response gene 1 (Egr-1) is required for new and reactivated fear memories in the lateral amygdala. Learn Mem. 2010;18:24-38. https://doi.org/10.1101//m.1980211.

176. Meaney MJ, Diorio J, Francis D, Weaver S, Yau J, Chapman K, et al. Postnatal handling increases the expression of CAMP-inducible transcription factors in the rat hippocampus: the effects of thyroid hormones and serotonin. J Neurosci. 2000;20:3926-35. http://www.ncbi.n/m.nih.gov/pubmed/ 10804232. Accessed 30 Dec 2017

177. Gröger N, Bock J, Goehler D, Blume N, Lisson N, Poeggel G, et al. Stress in utero alters neonatal stress-induced regulation of the synaptic plasticity proteins Arc and Egr1 in a sex-specific manner. Brain Struct Funct. 2016;221: 679-85. https://doi.org/10.1007/s00429-014-0889-3.

178. Revest J-M, Di Blasi F, Kitchener P, Rougé-Pont F, Desmedt A, Turiault M, et al. The MAPK pathway and Egr-1 mediate stress-related behavioral effects of glucocorticoids. Nat Neurosci. 2005;8:664-72. https:/doi.org/10.1038/nn1441.

179. Bossers K, Wirz KTS, Meerhoff GF, Essing AHW, Van Dongen JW, Houba P, et al. Concerted changes in transcripts in the prefrontal cortex precede neuropathology in Alzheimer's disease. Brain. 2010;133:3699-723. https://doi.org/10.1093/brain/awq258.

180. Zhu Q-B, Unmehopa U, Bossers K, Hu Y-T, Verwer R, Balesar R, et al. MicroRNA-132 and early growth response-1 in nucleus basalis of Meynert during the course of Alzheimer's disease. Brain. 2016;139:908-21. https://doi. org/10.1093/brain/awv383.

181. Dickey CA, Loring JF, Montgomery J, Gordon MN, Eastman PS, Morgan D. Selectively reduced expression of synaptic plasticity-related genes in amyloid precursor protein + presenilin-1 transgenic mice. J Neurosci. 2003;23:5219-26. http://www.jneurosci.org/content/jneuro/23/12/5219.full.pdf. Accessed 30 Dec 2017

182. Wirz KTS, Bossers K, Stargardt A, Kamphuis W, Swaab DF, Hol EM, et al. Cortical beta amyloid protein triggers an immune response, but no synaptic changes in the APPswe/PS1dE9 Alzheimer's disease mouse model. Neurobiol Aging. 2013;34:1328-42. https://doi.org/10.1016/j.neurobiolaging. 2012.11.008.

183. Qin X, Wang Y, Paudel HK. Inhibition of early growth response 1 in the hippocampus alleviates neuropathology and improves cognition in an Alzheimer model with plaques and tangles. Am J Pathol. 2017;187:1828-47. https://doi.org/10.1016/j.ajpath.2017.04.018.

184. Qin X, Wang Y, Paudel HK. Early growth response 1 (Egr-1) is a transcriptional activator of $\beta$-secretase 1 (BACE-1) in the brain. J Biol Chem. 2016;291:22276-87. https://doi.org/10.1074/jbc.M116.738849.

185. James AB, Conway A-M, Morris BJ. Genomic profiling of the neuronal target genes of the plasticity-related transcription factor-Zif268. J Neurochem. 2005;95:796-810. https://doi.org/10.1111/j.1471-4159.2005.03400.x.
186. Li L, Carter J, Gao X, Whitehead J, Tourtellotte WG. The neuroplasticityassociated arc gene is a direct transcriptional target of early growth response (EGR) transcription factors. Mol Cell Biol. 2005;25:10286-300. https://doi.org/10.1128/MCB.25.23.10286-10300.2005.

187. Link W, Konietzko U, Kauselmann G, Krugt M, Schwanke B, Frey U, et al. Somatodendritic expression of an immediate early gene is regulated by synaptic activity. Proc Natl Acad Sci U S A. 1995;92:5734-8. http://www.pnas. org/content/92/12/5734.full.pdf. Accessed 30 Dec 2017

188. Rodríguez JJ, Davies HA, Silva AT, De Souza IEJ, Peddie CJ, Colyer FM, et al. Long-term potentiation in the rat dentate gyrus is associated with enhanced Arc/Arg3.1 protein expression in spines, dendrites and glia. Eur J Neurosci. 2005;21:2384-96. https://doi.org/10.1111/j.1460-9568.2005.04068.x.

189. Bloomer WAC, VanDongen HMA, VanDongen AMJ. Activity-regulated cytoskeleton-associated protein Arc/Arg3.1 binds to spectrin and associates with nuclear promyelocytic leukemia (PML) bodies. Brain Res. 2007;1153:20-33. https://doi.org/10.1016/J.BRAINRES.2007.03.079.

190. Kelly M, Deadwyler S. Acquisition of a novel behavior induces higher levels of Arc mRNA than does overtrained performance. Neuroscience. 2002;110: 617-26. https://doi.org/10.1016/S0306-4522(01)00605-4.

191. Morin J-P, Díaz-Cintra S, Bermúdez-Rattoni F, Delint-Ramírez I. Decreased levels of NMDA but not AMPA receptors in the lipid-raft fraction of 3xTg-AD model of Alzheimer's disease: relation to Arc/Arg3.1 protein expression. Neurochem Int. 2016;100:159-63. https://doi.org/10.1016/j.neuint.2016.09.013.

192. Morin J-P, Cerón-Solano G, Velázquez-Campos G, Pacheco-López G, BermúdezRattoni F, Díaz-Cintra S. Spatial memory impairment is associated with intraneural amyloid- $\beta$ immunoreactivity and dysfunctional Arc expression in the hippocampal-CA3 region of a transgenic mouse model of Alzheimer's disease. J Alzheimers Dis. 2016;51:69-79. https://doi.org/10.3233/JAD-150975.

193. Rudinskiy N, Hawkes JM, Betensky RA, Eguchi M, Yamaguchi S, Spires-Jones $T L$, et al. Orchestrated experience-driven Arc responses are disrupted in a mouse model of Alzheimer's disease. Nat Neurosci. 2012;15:1422-9. https:// doi.org/10.1038/nn.3199.

194. Wu J, Petralia RS, Kurushima H, Patel H, Jung M, Volk L, et al. Arc/Arg3.1 regulates an endosomal pathway essential for activity-dependent $\beta$-amyloid generation. Cell. 2011;147:615-28. https://doi.org/10.1016/j.cell.2011.09.036.

195. Béïque J-C, Na Y, Kuhl D, Worley PF, Huganir RL. Arc-dependent synapsespecific homeostatic plasticity. Proc Natl Acad Sci U S A. 2011;108:816-21. https://doi.org/10.1073/pnas.1017914108.

196. Rial Verde EM, Lee-Osbourne J, Worley PF, Malinow R, Cline HT. Increased expression of the immediate-early gene arc/arg3.1 reduces AMPA receptormediated synaptic transmission. Neuron. 2006;52:461-74. https://doi.org/10. 1016/j.neuron.2006.09.031.

197. Shi S, Hayashi Y, Esteban JA, Malinow R. Subunit-specific rules governing AMPA receptor trafficking to synapses in hippocampal pyramidal neurons. Cell. 2001;105:331-43. http://www.ncbi.nlm.nih.gov/pubmed/11348590. Accessed 18 Feb 2018

198. Renner MC, Albers EH, Gutierrez-Castellanos N, Reinders NR, van Huijstee AN, Xiong $H$, et al. Synaptic plasticity through activation of GluA3containing AMPA-receptors. elife. 2017;6. https://doi.org/10.7554/eLife.25462.

199. Makino H, Malinow R. Compartmentalized versus global synaptic plasticity on dendrites controlled by experience. Neuron. 2011;72:1001-11. https://doi. org/10.1016/j.neuron.2011.09.036.

200. Molteni R, Chourbaji S, Brandwein C, Racagni G, Gass P, Riva M. Depressionprone mice with reduced glucocorticoid receptor expression display an altered stress-dependent regulation of brain-derived neurotrophic factor and activity-regulated cytoskeleton-associated protein. J Psychopharmacol. 2010;24:595-603. https://doi.org/10.1177/0269881108099815.

201. Chen A, Kelley LDS, Janušonis S. Effects of prenatal stress and monoaminergic perturbations on the expression of serotonin $5-\mathrm{HT}_{4}$ and adrenergic $\beta_{2}$ receptors in the embryonic mouse telencephalon. Brain Res. 2012;1459:27-34. https://doi.org/10.1016/j.brainres.2012.04.019.

202. Wegenast-Braun BM, Fulgencio Maisch A, Eicke D, Radde R, Herzig MC, Staufenbiel $M$, et al. Independent effects of intra- and extracellular $A \beta$ on learning-related gene expression. Am J Pathol. 2009;175:271-82. https://doi. org/10.2353/AJPATH.2009.090044

203. Palop JJ, Chin J, Bien-Ly N, Massaro C, Yeung BZ, Yu G-Q, et al. Vulnerability of dentate granule cells to disruption of Arc expression in human amyloid precursor protein transgenic mice. J Neurosci. 2005;25:9686-93. https://doi. org/10.1523/JNEUROSCl.2829-05.2005.

204. Palop JJ, Chin J, Roberson ED, Wang J, Thwin MT, Bien-Ly N, et al. Aberrant excitatory neuronal activity and compensatory remodeling of inhibitory 
hippocampal circuits in mouse models of Alzheimer's disease. Neuron. 2007; 55:697-711. https://doi.org/10.1016/..neuron.2007.07.025.

205. de Rooij SR, Wouters H, Yonker JE, Painter RC, Roseboom TJ. Prenatal undernutrition and cognitive function in late adulthood. Proc Natl Acad Sci U S A. 2010;107:16881-6. https://doi.org/10.1073/pnas.1009459107.

206. de Rooij SR, Caan MWA, Swaab DF, Nederveen AJ, Majoie CB, Schwab M, et al. Prenatal famine exposure has sex-specific effects on brain size. Brain. 2016;139(Pt 8):2136-42. https://doi.org/10.1093/brain/aww132.

207. Franke K, Gaser C, Roseboom TJ, Schwab M, de Rooij SR. Premature brain aging in humans exposed to maternal nutrient restriction during early gestation. Neurolmage. 2018;173:460-71. https://doi.org/10.1016/j. neuroimage.2017.10.047.

208. Staufenbiel SM, Penninx BWJH, Spijker AT, Elzinga BM, van Rossum EFC. Hair cortisol, stress exposure, and mental health in humans: a systematic review. Psychoneuroendocrinology. 2013;38:1220-35. https://doi.org/10.1016/j. psyneuen.2012.11.015.

209. Kulstad JJ, McMillan PJ, Leverenz JB, Cook DG, Green PS, Peskind ER, et al. Effects of chronic glucocorticoid administration on insulin-degrading enzyme and amyloid- $\beta$ peptide in the aged macaque. J Neuropathol Exp Neurol. 2005;64:139-46. https://doi.org/10.1093/jnen/64.2.139.

210. Pomara N, Doraiswamy PM, Tun $H$, Ferris S. Mifepristone (RU 486) for Alzheimer's disease. Neurology. 2002;58:1436. https://doi.org/10.1212/WNL. 58.9.1436.

211. Lemaire V, Koehl M, Le Moal M, Abrous DN. Prenatal stress produces learning deficits associated with an inhibition of neurogenesis in the hippocampus. Proc Natl Acad Sci U S A. 2000;97:11032-7. http://www.ncbi. nlm.nih.gov/pubmed/11005874. Accessed 5 Feb 2018

212. Arenaza-Urquijo EM, Vemuri P. Resistance vs resilience to Alzheimer disease: clarifying terminology for preclinical studies. Neurology. 2018;90:695-703. https://doi.org/10.1212/WNL.0000000000005303.

213. Almeida RP, Schultz SA, Austin BP, Boots EA, Dowling NM, Gleason CE, et al. Effect of cognitive reserve on age-related changes in cerebrospinal fluid biomarkers of Alzheimer disease. JAMA Neurol. 2015;72:699. https://doi.org/ 10.1001/jamaneurol.2015.0098.

214. Stern Y. Cognitive reserve in ageing and Alzheimer's disease. Lancet Neurol. 2012;11:1006-12. https://doi.org/10.1016/S1474-4422(12)70191-6.

215. Katzman R. Education and the prevalence of dementia and Alzheimer's disease. Neurology. 1993;43:13-20. http://www.ncbi.nlm.nih.gov/pubmed/ 8423876. Accessed 18 Apr 2017

216. Hsiao K, Chapman P, Nilsen S, Eckman C, Harigaya Y, Younkin S, et al. Correlative memory deficits, Abeta elevation, and amyloid plaques in transgenic mice. Science. 1996;274:99-102. http://www.ncbi.nlm.nih.gov/ pubmed/8810256. Accessed 3 Jan 2018

217. Jankowsky JL, Slunt HH, Gonzales V, Jenkins NA, Copeland NG, Borchelt DR. APP processing and amyloid deposition in mice haplo-insufficient for presenilin 1. Neurobiol Aging. 2004;25:885-92. https://doi.org/10.1016/j. neurobiolaging.2003.09.008.

218. Janus C, Flores AY, Xu G, Borchelt DR. Behavioral abnormalities in APPSwe/ PS1dE9 mouse model of AD-like pathology: comparative analysis across multiple behavioral domains. Neurobiol Aging. 2015;36:2519-32. https://doi. org/10.1016/..neurobiolaging.2015.05.010.

219. Yoshiyama Y, Higuchi M, Zhang B, Huang S-M, Iwata N, Saido TC, et al. Synapse loss and microglial activation precede tangles in a P301S tauopathy mouse model. Neuron. 2007;53:337-51. https://doi.org/10.1016/j. neuron.2007.01.010.

220. Terwel D, Lasrado R, Snauwaert J, Vandeweert E, Van Haesendonck C, Borghgraef $\mathrm{P}$, et al. Changed conformation of mutant Tau-P301L underlies the moribund tauopathy, absent in progressive, nonlethal axonopathy of tau-4R/2N transgenic mice. J Biol Chem. 2005;280:3963-73. https://doi.org/ 10.1074/jbc.M409876200

221. Lewis J, Dickson DW, Lin WL, Chisholm L, Corral A, Jones G, et al. Enhanced neurofibrillary degeneration in transgenic mice expressing mutant tau and APP. Science. 2001;293:1487-91. https://doi.org/10.1126/science.1058189.

222. Terwel D, Muyllaert D, Dewachter I, Borghgraef $P$, Croes S, Devijver $H$, et al. Amyloid activates GSK-3 3 to aggravate neuronal tauopathy in bigenic mice. Am J Pathol. 2008;172:786-98. https://doi.org/10.2353/ajpath.2008.070904.

223. Oddo S, Caccamo A, Shepherd JD, Murphy MP, Golde TE, Kayed R, et al. Triple-transgenic model of Alzheimer's disease with plaques and tangles: intracellular Abeta and synaptic dysfunction. Neuron. 2003;39:409-21. http://www.ncbi.nlm.nih.gov/pubmed/12895417. Accessed 3 Jan 2018
224. Oakley H, Cole SL, Logan S, Maus E, Shao P, Craft J, et al. Intraneuronal betaamyloid aggregates, neurodegeneration, and neuron loss in transgenic mice with five familial Alzheimer's disease mutations: potential factors in amyloid plaque formation. J Neurosci. 2006;26:10129-40. https://doi.org/10. 1523/JNEUROSCI.1202-06.2006.

225. Saul A, Sprenger F, Bayer TA, Wirths O. Accelerated tau pathology with synaptic and neuronal loss in a novel triple transgenic mouse model of Alzheimer's disease. Neurobiol Aging. 2013;34:2564-73. https://doi.org/10. 1016/j.neurobiolaging.2013.05.003.

226. Guzmán E, Bouter $Y$, Richard BC, Lannfelt L, Ingelsson M, Paetau A, et al. Abundance of AB5-x like immunoreactivity in transgenic 5XFAD, APP/PS1KI and 3XTG mice, sporadic and familial Alzheimer's disease. Mol Neurodegener. 2014;9:13. https://doi.org/10.1186/1750-1326-9-13.

227. Yin Z, Raj D, Saiepour N, Van Dam D, Brouwer N, Holtman IR, et al. Immune hyperreactivity of $A \beta$ plaque-associated microglia in Alzheimer's disease. Neurobiol Aging. 2017;55:115-22. https://doi.org/10.1016/j.neurobiolaging. 2017.03.021.

228. Wirths O, Walter S, Kraus I, Klafki HW, Stazi M, Oberstein TJ, et al. N-truncated Aß4-x peptides in sporadic Alzheimer's disease cases and transgenic Alzheimer mouse models. Alzheimers Res Ther. 2017;9:80. https:/doi.org/10.1186/s13195017-0309-z.

229. Caldji C, Tannenbaum B, Sharma S, Francis D, Plotsky PM, Meaney MJ. Maternal care during infancy regulates the development of neural systems mediating the expression of fearfulness in the rat. Proc Natl Acad Sci U S A. 1998;95:5335-40. http://www.ncbi.nlm.nih.gov/pubmed/9560276. Accessed 8 Dec 2017

230. Huot RL, Plotsky PM, Lenox RH, McNamara RK. Neonatal maternal separation reduces hippocampal mossy fiber density in adult Long Evans rats. Brain Res. 2002;950:52-63. https://doi.org/10.1016/S0006-8993(02)02985-2.

231. Rice CJ, Sandman CA, Lenjavi MR, Baram TZ. A novel mouse model for acute and long-lasting consequences of early life stress. Endocrinology. 2008;149:4892-900. https://doi.org/10.1210/en.2008-0633.

232. Avishai-Eliner S, Eghbal-Ahmadi M, Tabachnik E, Brunson KL, Baram TZ. Down-regulation of hypothalamic corticotropin-releasing hormone messenger ribonucleic acid (mRNA) precedes early-life experience-induced changes in hippocampal glucocorticoid receptor mRNA. Endocrinology. 2001;142:89-97.

233. Meaney M, Aitken D, van Berkel C, Bhatnagar S, Sapolsky R. Effect of neonatal handling on age-related impairments associated with the hippocampus. Science. 1988;239(4841 Pt 1):766-8. http://www.ncbi.nlm.nih. gov/pubmed/3340858. Accessed 27 Jan 2016

234. Weinberg J, Levine S. Early handling influences on behavioral and physiological responses during active avoidance. Dev Psychobiol. 1977;10:161-9. https:/doi. org/10.1002/dev.420100209.

\section{Ready to submit your research? Choose BMC and benefit from:}

- fast, convenient online submission

- thorough peer review by experienced researchers in your field

- rapid publication on acceptance

- support for research data, including large and complex data types

- gold Open Access which fosters wider collaboration and increased citations

- maximum visibility for your research: over 100M website views per year

At BMC, research is always in progress.

Learn more biomedcentral.com/submissions 